\title{
Teknoloji Bağlamında Eğitimde Fursat Eşitsizliği: Eğitime Erişime Yönelik Sorunlar ve Çözüm Önerileri
}

\author{
Metin IŞIK \\ Kırşehir Ahi Evran Üniversitesi \\ isik.metin@ahievran.edu.tr \\ ORCID: 0000-0002-7431-4091 \\ İsa BAHAT \\ Kırşehir Ahi Evran Üniversitesi \\ isabahat@ahievran.edu.tr \\ ORCID: 0000-0003-1535-3461
}

\begin{tabular}{lrr} 
Araştırma Makalesi & DOI: 10.31592/aeusbed.908232 \\
\hline Geliş Tarihi: 02.04. 2021 & Revize Tarihi: 23.06.2021 & Kabul Tarihi: 25.06.2021
\end{tabular}

\section{Atıf Bilgisi}

Işık, M. ve Bahat, İ. (2021). Teknoloji bağlamında eğitimde fırsat eşitsizliği: eğitime erişime yönelik sorunlar ve çözüm önerileri. Ahi Evran Üniversitesi Sosyal Bilimler Enstitüsü Dergisi, 7(2), 498-517.

\section{ÖZ}

Bu araștırmanın amacı, Koronavirüs (Covid 19) salgını sürecinde teknoloji bağlamında firsat eşitsizliği nedeniyle eğitime erişimde öğrencilerin yaşadıkları sorunların ve çözüm önerilerinin belirlenmesidir. Bu çalışma nicel araştırma yöntemini esas alan, tarama desenli bir araştırmadır. $\mathrm{Bu}$ araştırmanın örneklemini, İstanbul ili Beylikdüzü ilçesindeki bir ilkokul, Büyükçekmece ilçesindeki bir Anadolu lisesi ve Kırşehir ili Kaman ilçesindeki bir imam hatip ortaokulunda çocuğu öğrenci olan 558 veli oluşturmaktadır. Verilerin toplanması için oluşturulan çevrimiçi form 2020-2021 eğitim öğretim yılı güz döneminde uygulanmıştır. Hazırlanan çevrimiçi ankette öğrencilerin eğitime erişim olanakları; ailelerinin sosyo-ekonomik düzeyi, eğitim seviyesi ve ekonomik yeterlikleri, eğitim teknolojileri ve internet olanaklarını belirlemeye yönelik sorular yer almıştır. Koronavirüs salgın sürecinden başta öğrenciler olmak üzere eğitim sisteminin paydaşları öğretmenler, yöneticiler ve veliler de etkilenmiştir. Eğitimin uzaktan gerçekleştirildiği bu süreçte öğrencilerin somut öğrenmeyi deneyimleyememeleri nedeniyle eğitime erişimin önemi daha görünür hale gelmiştir. Özellikle eğitim teknolojilerine sahip olabilme açısından firsat eşitliği bağlamında eğitim sistemindeki sorunlar daha belirginleşmiştir. Uzaktan eğitim sürecinde öğrencilerin eğitime eşit erişimlerini sağlayacak olanakların sunulmasına yönelik gerekli düzenlemelerin yapılması ve gereksinimlerini karşılamak için önlemlerin alınması salgının geleceğe yönelik olumsuz etkilerini azaltacaktır.

Anahtar Kelimeler: Fırsat eşitliği, uzaktan eğitim, eğitime erişim.

\section{Inequality of Opportunity in Education and Problems and Solutions Regarding Access To Education in The Context Of Technology}

\begin{abstract}
The purpose of this research is to determine the problems experienced by students in accessing education due to the inequality of opportunity in the context of technology during the Corona virus (Covid 19) epidemic and solution suggestions. This study is a scan-patterned study based on a quantitative research method. The sample of this research consists of 558 parents whose children are students in an elementary school in Beylikdüzü district of Istanbul province, an Anatolian high school in Büyükçekmece district and an Imam Hatip secondary school in Kaman district of Kirşehir. The online form created for the collection of data was implemented in the fall semester of the 2020-2021 academic year. The online survey included questions about determining students' access to education, their families' socio-economic level, education level, and economic competencies, educational technologies, and internet opportunities. Teachers, administrators, and parents, especially students, were affected by the coronavirus pandemic. The importance of access to education has become more visible due to the inability of students to experience concrete learning in this process where education is carried out remotely. Especially in terms of having educational technologies, problems in the education system have become more clarified in the context of equality of opportunity. Making the necessary arrangements to provide opportunities for students to have equal access to education and taking precautions to meet their needs in the online education process will reduce the negative effects of the pandemic for the future.
\end{abstract}

Keywords: Equality of opportunity, distance learning, access to education. 


\section{Giriş}

Koronavirüs salgını, başta öğrenciler olmak üzere öğretmenler, yöneticiler ve velileri etkilemiştir. Bu süreçte eğitimin yüz yüze yapılamaması nedeniyle yaşanan eğitime erişim sorunuyla birlikte öğrenme kayıpları artmış, sürekli öğrenme, sosyal öğrenme ve sınıf içi etkileşimi yansıtan akran paylaşımları azalmıştır. Salgın süreci özellikle firsat eşitliği açısından eğitim sistemindeki sorunları daha görünür kılmıştır. Salgının kaçınılmaz bir sonucu olarak birçok ülkede ve ülkemizde uzaktan eğitime geçilmiştir. $\mathrm{Bu}$ dönemde eğitimin sürekliliğini sağlamak için bir zorunluluk olarak başlayan uzaktan eğitim, mevcut eğitim teknolojileri ve altyapı eksiklikleri ile öğrencilerin somut öğrenmeleri bağlamında eğitime erişimin önemini göstermektedir. Özer ve Eren Suna (2020), koronavirüs sonrası salgının yol açabileceği firsat eşitsizliklerinin toplumlarda kalıcı olmaması ve daha fazla derinleşmemesi için özellikle dezavantajlı okullarda telafi edici ek eğitimlerin yapılmasının önemine dikkat çekmektedir. Yıldız ve Akar Vural (2020) da Koronavirüs krizinden özellikle toplumların kırılgan nüfus gruplarının daha fazla etkilendiği hem bireysel hem de toplumsal düzeyde artan eğitim eşitsizlikleri okulların eşit olanaklara sahip olmasıyla giderilebileceğini belirtmiştir. Bireyler, toplumsal eşitlik hedefi ile eğitime erişimde eşit olanaklara sahip olmayı beklemektedir. Eşitlik, eğitim sisteminde başarılı bireylerin bu başarıya ulaşmaları sürecinde onlara sağlanan firsat ve imkânlarla ilgilidir. Eşitliğin ölçütleri de akademik başarı, sosyo-ekonomik düzey, cinsiyet ve eğitime erişim olarak ifade edilir. Okullar ve bölgeler arasında kaynakların dağıtımı öğrenmede firsat eşitsizliklerine neden olabilmektedir. Bu yüzden özellikle Koronavirüs döneminde eğitime erişimde öğrencilerin olanaklarının doğru belirlenmesi ile tespit edilen eşitsizlikleri gidermeye yönelik ulusal ve uluslararası önlemler alınması beklenmektedir.

Eğitimde firsat eşitliği, bireysel ve sosyal açıdan önemli etkileri bulunan çok boyutlu bir olgudur. Eğitimde firsat eşitliğinin en görünür, belirgin şekli başarı olanaklarında eşitliktir (Eğitim Reformu Girişimi [ERG], 2020). Eşitlik, etik ve sosyal bir ideal olarak bireylerin aynı konum ve değerde olmaları halidir (Mercik, 2015). Firsat eşitliği, bireylerin hayatta başarılı olmaları için mevcut firsatlara ya da olanaklara sahip olmaları gerektiği görüşüne dayanmaktadır (Ashford, 2015). Öğrenme ortamlarının niteliğinin eşitlik ilkesine uygun geliştirilerek eğitimde firsat eşitliğinin sağlanması için zorunlu eğitim süresi, fiziki olanaklar ve okullaşma oranlarının artması, teknolojik alt yapının güçlendirilmesi önemlidir. Eğitimde firsat eşitliği olgusu bölgesel özellikler, öğrenci özellikleri, ailenin sosyo-ekonomik durumu, öğrenci başarısı, okul etkisi bağlamında değerlendirilmelidir (Gamoran ve Long, 2007). Anne-babaların eğitim düzeyi arttıkça çocuğun okula yönelmesi ve eğitimlerine devam etme şansının da artması eşitlik kapsamını aileye indirgemektedir. Çünkü ailelerin sosyo-ekonomik durumları ve kültürel özellikleri, çocukların eğitiminde belirleyici olabilmektedir (Buyruk, 2008). Aile, çocuğun toplumsal kültürü öğrendiği ve sosyalleştiği ilk ortamıdır. Ailelerin çocuk yetiştirme yöntemleri, eğitim seviyeleri ve sosyoekonomik düzeyleri çocukların farklılaşmaları yönünde belirleyici faktörlerdir (Tezcan, 1985). Ayrıca bölgesel farklılıklar, sosyo-ekonomik koşullar, sosyokültürel altyapı, eğitime erişim, eğitim düzeyi ve toplumsal cinsiyet firsat eşitliğinin önündeki engeller olarak önemli görülmektedir (Mercik, 2015). Bu açıdan toplumda eşitliğin sağlanması için (Anderson, 2007): a)Sorunların çözümünde bilgi, b) akademik bilgi ve bu kişilerin tutumları, c) karar vericilerin toplumsal eşitliğin sağlanmasına yönelik tutumları, d) kişisel bilgi için gerekli sosyal ve kültürel sermayenin oluşması gereklidir.

Eğitimin her kademesinde günümüzde ortaya çıkan değişiklikler sonucunda yaşanan sorunlar ve sunulan çözüm önerileri öğrencileri etkilemektedir. Okul öncesi eğitimde kapasite sınırlılı̆̆ ve yetersizlikler, ortaöğretimdeki yapısal eşitsizlikler ve nitelik sorunları bütün öğretimi olumsuz etkilemektedir (Türk Eğitim Derneği (TED), 2007). Tüm bireyler eğitim sistemi içerisinde iyi bir öğrenim görme ve temel becerilere sahip olma firsatına sahip olmalıdır (Organisation for Economic Co-operation and Development [OECD], 2012). Bu yüzden eğitimde eşitlik için ailelerin sosyo-ekonomik seviyesi, yaşadıkları yer, öğrencinin cinsiyeti gibi etkenlerden bağımsız olarak eğitim olanaklarına erişimde bireysel ve sosyal koşulların sağlanması önemli görülür (Schleicher, 2009). Eğitim kararlarının alınmasında ailenin ekonomik geliri önemli bir standart aracıdır. Ailelerin temel eğitimi tamamlama isteği 
ve üniversiteye kayıt yaptırma ihtimali aile bütçesine bağlı olarak gelir artışı ile okullaşma oranlarının artacağı tahmin edilebilir (Acemoğlu ve Pischke, 2001). Eğitimde yaşanan eşitsizliklerin temelinde bulunan ve eğitimi olumsuz etkileyen alanlarda eşitsizliklerin görülmesinden dolayı fırsat eşitliği anlayış1 yerine; sinıflar, cinsiyetler, bölgeler arasındaki ekonomik, toplumsal ve kültürel eşitsizliklerin giderilmesini de içeren bir "eşitlik" anlayışı getirilmelidir (Küçüker, 2010). Normal şartlarda eğitimde her bireye eşit olanakların, fırsatların tanınması hedeflenmektedir. Devletin herkes için sağlık, güvenlik ve eğitim haklarını sağlaması toplumsal refah ortamına katkı sağlayacaktır. Sistem bağlamında sunulan eğitim firsatlarının eşitlik açısından değerlendirilmesi, eğitimde fırsat eşitliğini sağlayan aile yapısı, okul yönetimi (bina, öğretim programı, öğretmenler vb.), öğrencilerin eğitim geçmişi, okullaşma oranları gibi unsurların karşılaştırılması ile gerçekleştirilebilir. Gerek bölgeler gerekse kırsal ve kentsel yerleşim alanları arasında sosyo-ekonomik yapı ve gelir düzeyi açısından farklılıklar söz konusudur. Bu eşitsizlik içinde eğitim hakkının kullanılabilmesi de ailelerin ekonomik ve sosyal durumlarına bağlıdır. Bu yüzden firsat eşitliğinde olan farklar öğrencilerin akademik başarısını da etkilemektedir (Sarıbaş ve Babadă̆, 2015). Ayrıca ailelerin ekonomik, sosyal ve kültürel farklılıkları da öğrencilerin eğitime erişiminde önemli rol oylamaktadır (Ömür, Bahat ve Ernas, 2017). Eşitlik ilkesinin ölçüsü "yeterli” olması, yeterli olmanın ölçütü ise kişilerin genel dağılımı ile ilgilidir. Ancak eğitimde yeterlilik ölçütü daha az avantajlı öğrenciler için avantajlı uygulamalara sahip olma düzeyidir (Satz, 2008). Uzaktan eğitim ile evde eğitim süreci, her bir öğrenen için sessiz, dikkati dağıtacak minimum uyaranın olduğu bireysel bir öğrenme mekanı, yüksek hızlı bir internet bağlantısı, diğerleri ile paylaşmaya gereksinim duyulmayan bilgisayar, kulaklık, kamera gibi bireysel ekipmanlar, ebeveyn rehberliği gibi yeni gereksinimler yaratmıştır (Yıldız ve Akar Vural, 2020). Uzaktan eğitim ile öğrencilerin evlerinde eğitimlerini sürdürebilmeleri için ailelerin de uzaktan eğitim sürecine destek vermeleri gerekmektedir. Ancak yaşanan sürece hazırlıksız yakalanılması uzaktan eğitim ortamlarında eğitim-öğretimin istenilen düzeyde gerçekleştirilmesini engellemiştir (Iş̧1k ve Bahat, 2021). Bu çalışmada Koronavirüs salgınının eğitime erişim, teknolojik olanaklar ve yeterlik bağlamında yaşananların fırsat eşitliği açısından değerlendirilmesi ve çözüm önerilerinin belirlenmesi amaçlanmaktadır. Bu amaçla aşağıdaki sorulara cevap aranmıştır:

a) Uzaktan eğitim sürecinde çevrimiçi derslere erişimde ne tür sorun/sorunlar yaşanmaktadır?

b) Uzaktan eğitim ile öğrencilere eşit öğrenme firsatları/erişim olanakları nelerdir?

c) Uzaktan eğitim ile öğrencilere sunulan öğrenme firsatları yeterli midir?

d) Uzaktan eğitim sürecinin iyileştirilmesine/geliştirilmesine yönelik öneriler nelerdir?

\section{Yöntem}

\section{Araștırmanın Modeli}

$\mathrm{Bu}$ araştırmada, farklı kademelerdeki okullarda öğrenim gören çocukların velilerinin görüşleri doğrultusunda Koronavirüs salgınının eğitime erişim ve teknolojik olanaklar bağlamında yaşananların fırsat eşitliği açısından değerlendirilmesi ve çözüm önerilerinin belirlenmesi amaçlandığından tarama deseni kullanılmıştır. Tarama deseni; bireylerin ve grupların belirli özelliklerini tespit etmek, istenilen olgunun bütününü ortaya koymak amacıyla kullanılmaktadır (Yıldırım ve Şimşek, 2013).

\section{Evren ve Örneklem}

Araştırmanın örneklemini, İstanbul il merkezindeki Beylikdüzü ilçesinde bulunan bir ilkokul ile Büyükçekmece ilçesinde bulunan bir lisede çocuğu öğrenci olan veliler ve Kırşehir ili Kaman ilçesinde bulunan İmam Hatip ortaokulu öğrencilerinin velileri oluşturmaktadır. Araştırmada amaçlı örnekleme tekniklerinden maksimum çeşitlilik örneklem seçimine gidilmiştir. Maksimum çeşitlilik örnekleme ile amaç birtakım farklılıkları içeren temel temaları bulup tanımlamaktır (Patton, 2014). Her bir okul türü bir alt evren olarak kabul edilmiştir. Katılımcı velilerin yaşadıkları yer ve çocuklarının öğrenim gördüğü okul türü ve düzeyine göre belirlenen örneklemin evreni temsil etmesi hedeflenmiştir. Her kademeden okul 
velilerine ulaşıldığg için evrenin tamamına ulaşılmasının olanaksızlığı doğrultusunda örneklemin evreni temsil ettiği varsayılmıştır.

\section{Veri Toplama Aracı}

Çalışmada araştırmacılar tarafından oluşturulan anket kullanılmıştır. Kapsam geçerliliğini sağlamak amacıyla alanyazın incelenerek anket maddeleri oluşturulmuştur. Kapsam geçerliliğinin değerlendirilmesi amacıyla ölçme aracı 2 alan uzmanı ile paylaşılarak görüşleri doğrultusunda düzenlenerek ankete son hali verilmiştir.

\section{Verilerin Toplanması ve Analizi}

Veriler, 2020-2021 eğitim öğretim yılında 23 sorudan oluşan çevrim içi anket formu ile toplanmıştır. Verilerin çözümlenmesi uygun analiz yöntemleri ( $t$ testi, anova) kullanılmıştır. Veriler, SPSS 25 istatistik programı kullanılarak çözümlenmiştir.

\section{Araştırma Etiği}

$\mathrm{Bu}$ çalışmada "Yükseköğretim Kurumları Bilimsel Araştırma ve Yayın Etiği Yönergesi" kapsamında bütün kurallara uyulmuştur. Ayrıca bu çalışma için Kırşehir Ahi Evran Üniversitesi Sosyal ve Beşeri Bilimler Araştırma ve Yayın Etiği Kurulunun 04.03.2021 tarih ve 2021/1/42 sayılı etik kurul onay1 alınmıştır.

\section{Bulgular}

Elde edilen bulgular öncelikle demografik verileri değerlendirilmiştir. Demografik veriler betimsel istatistik yöntemleriyle analiz edilmiş katılımcılara ait cinsiyet, yaş, ailedeki rol, eğitim durumu, çocuk sayısı, aylık gelir ve yaşanılan yere ait veriler ayrı ayrı tablolarda frekans (f) ve yüzde (\%) değerleri hesaplanmıştır. Çalışmanın istatistiksel olarak anlamlı olup olmadığını anlamak için ise Chi-Square (kikare) testi uygulanarak sonuçlar elde edilmiş ve yorumlanmıştır.

Tablo 1

Uzaktan Eğitim Sürecinde Çevrimiçi Derslere Erişim İçin Yeni Bir Teknolojik Ekipman (Akıllı Telefon, Tablet, Masaüstü Bilgisayar, Taşınabilir Bilgisayar, Diğer) Satın Aldınız Mı? Sorusuna Verdiği Yanıtların Dağılımı

\begin{tabular}{lrr}
\hline & $f$ & \% \\
\hline Evet & 225 & 38,7 \\
Hayir & 333 & 57,2 \\
Toplam & 582 & 100,0 \\
\hline
\end{tabular}

Tablo 1'de görüldüğü üzere katılımcıların 225'i (\% 38,7) uzaktan eğitim sürecinde çevrimiçi derslere erişim için yeni bir teknolojik ekipman (akıllı telefon, tablet, masaüstü bilgisayar, taşınabilir bilgisayar, diğer) satın aldığını belirtirken, 333’ü (\% 57,2) herhangi bir yeni cihaz almadığını belirtmiştir.

Tablo 2

Katılımcıların MEB/YÖK Internetinden Haberdar Mısınız? Sorusuna Verdikleri Yanıtların Dağılımı

\begin{tabular}{lrr} 
& $\boldsymbol{f}$ & $\mathbf{\%}$ \\
\hline Evet & 249 & 42,8 \\
Hayı̀r & 309 & 53,1 \\
Belirtmemiş & 24 & 4,1 \\
Toplam & 582 & 100,0 \\
\hline
\end{tabular}


Tablo 2'de görüldüğü üzere katılımcıların 249’u (\% 42,8) Milli Eğitim Bakanlı̆̆1 (MEB) / Yükseköğretim Kurulu'nun (YÖK) ücretsiz sunduğu internet hizmetinden haberi olduğunu belirtirken, 309’u (\% 53,1) haberinin olmadığını belirtmiştir. Katılımcıların 24’ü (\% 4,1) görüş belirtmemiştir.

Tablo 3

Katılımcıların MEB/YÖK Sunduğu Ücretsiz İnternet Yeterli Oldu Mu? Sorusuna Verdiği Yanıtların Dağılımı

\begin{tabular}{lrr}
\hline & $\boldsymbol{f}$ & $\boldsymbol{\%}$ \\
\hline Evet & 73 & 12,5 \\
Hayıır & 290 & 49,8 \\
Belirtmemiş & 219 & 37,6 \\
Toplam & 582 & 100,0 \\
\hline
\end{tabular}

Tablo 3'te MEB/YÖK'ün sunduğu internet hizmetinden haberi olan katılımcıların 73'ü $(\%$ 12,5) bu hizmetin yeterli olduğunu belirtirken, katılımcıların 290'1 (\% 49,8) yetersiz olduğunu belirtmiş, 219'u $(\%$ 37,6) ise görüş belirtmemiştir.

Tablo 4

Katılımcıların İnternet Erişiminiz Kotalı/Sınırlı mı? Sorusuna Verdiği Yanıtların Dağılımı

\begin{tabular}{lrr}
\hline & $f$ & \% \\
\hline Kotalı & 138 & 23,7 \\
Sinırsız & 420 & 72,2 \\
Belirtmemiş & 24 & 4,1 \\
Toplam & 582 & 100,0 \\
\hline
\end{tabular}

Tablo 4'te katılımcıların 138'i (\% 23,7) internet erişimlerinin kotalı olduğunu belirtirken, 420'si (\% 72,2) sınırlı olduğunu belirtmiştir. Katılımcıların 24'ü $(\% 4,1)$ ise internet erişimlerine ilişkin görüş belirtmemiştir.

Tablo 5

Cinsiyet Değişkenine Göre Katılımcıların Verdiği Yanıtların Ki-Kare Testi Sonuçları

\begin{tabular}{|c|c|c|c|c|c|c|c|c|c|}
\hline & & & 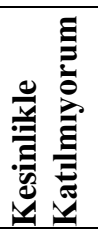 & 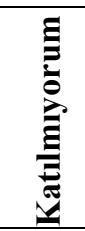 & 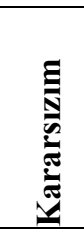 & 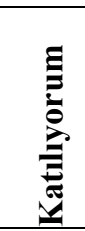 & 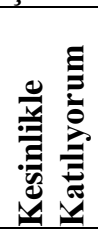 & $\mathbf{X}^{2}$ & $\mathbf{p}$ \\
\hline \multirow{2}{*}{$\begin{array}{l}\text { Çocuğum uzaktan eğitim sürecinde } \\
\text { çevrimiçi derslere erişimde } \\
\text { sorun/sorunlar yaşadı. }\end{array}$} & \multirow{2}{*}{ Toplam } & $\mathrm{n}$ & 78 & 78 & 176 & 101 & 125 & 1,327 & ,857 \\
\hline & & $\%$ & 14,0 & 14,0 & 31,5 & 18,1 & 22,4 & & \\
\hline \multirow{2}{*}{$\begin{array}{l}\text { Uzaktan eğitim ile öğrencilere eşit } \\
\text { öğrenme firsatları sunuldu. }\end{array}$} & \multirow{2}{*}{ Toplam } & $\mathrm{n}$ & 194 & 63 & 131 & 61 & 109 & 5,017 & ,286 \\
\hline & & $\%$ & 34,8 & 11,3 & 23,5 & 10,9 & 19,5 & & \\
\hline \multirow{2}{*}{$\begin{array}{l}\text { Uzaktan eğitim ile öğrencilere sunulan } \\
\text { ögrenme firsatları yeterlidir. }\end{array}$} & \multirow{2}{*}{ Toplam } & $\mathrm{n}$ & 194 & 107 & 146 & 64 & 47 & 4,770 & ,312 \\
\hline & & $\%$ & 34,8 & 19,2 & 26,2 & 11,5 & 8,4 & & \\
\hline \multirow{2}{*}{$\begin{array}{l}\text { Uzaktan eğitim ile çocuğum/çocuklarım } \\
\text { eğitim-öğretim olanaklarına diğer } \\
\text { çocuklarla eşit düzeyde erişti. }\end{array}$} & \multirow{2}{*}{ Toplam } & $\mathrm{n}$ & 131 & 71 & 142 & 100 & 114 & 6,008 & , 199 \\
\hline & & $\%$ & 23,5 & 12,7 & 25,4 & 17,9 & 20,4 & & \\
\hline
\end{tabular}

Yapılan araştırmada cinsiyet değişkenine göre sorulara verdikleri yanıtlarda gruplar arasında fark bulunmamaktadır. 
Tablo 6

Medeni Durum Değiş̧kenine Göre Katılımcıların Verdiği Yanıtların Ki-Kare Testi Sonuçları.

\begin{tabular}{|c|c|c|c|c|c|c|c|c|c|}
\hline & & & 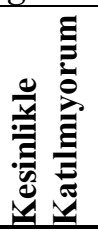 & 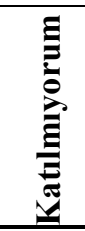 & 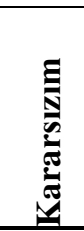 & 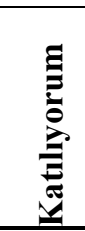 & 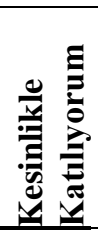 & $\mathrm{X}^{2}$ & $\mathbf{p}$ \\
\hline \multirow{2}{*}{$\begin{array}{l}\text { Çocuğum uzaktan eğitim sürecinde } \\
\text { çevrimiçi derslere erişimde } \\
\text { sorun/sorunlar yaşadı. }\end{array}$} & \multirow{2}{*}{ Toplam } & $\mathrm{n}$ & 78 & 78 & 176 & 101 & 125 & 2,175 &, 704 \\
\hline & & $\%$ & 14,0 & 14,0 & 31,5 & 18,1 & 22,4 & & \\
\hline \multirow{2}{*}{$\begin{array}{l}\text { Uzaktan eğitim ile öğrencilere eşit } \\
\text { öğrenme firsatları sunuldu. }\end{array}$} & \multirow{2}{*}{ Toplam } & $\mathrm{n}$ & 194 & 63 & 131 & 61 & 109 & 3,242 & ,518 \\
\hline & & $\%$ & 34,8 & 11,3 & 23,5 & 10,9 & 19,5 & & \\
\hline \multirow{2}{*}{$\begin{array}{l}\text { Uzaktan eğitim ile öğrencilere sunulan } \\
\text { öğrenme firsatları yeterlidir. }\end{array}$} & \multirow{2}{*}{ Toplam } & $\mathrm{n}$ & 194 & 107 & 146 & 64 & 47 & 3,605 & ,462 \\
\hline & & $\%$ & 34,8 & 19,2 & 26,2 & 11,5 & 8,4 & & \\
\hline \multirow{2}{*}{$\begin{array}{l}\text { Uzaktan eğitim ile çocuğum/çocuklarım } \\
\text { eğitim-öğretim olanaklarına diğer } \\
\text { çocuklarla eşit düzeyde erişti. }\end{array}$} & \multirow{2}{*}{ Toplam } & $\mathrm{n}$ & 131 & 71 & 142 & 100 & 114 & ,534 & ,970 \\
\hline & & $\%$ & 23,5 & 12,7 & 25,4 & 17,9 & 20,4 & & \\
\hline
\end{tabular}

Yapılan araştırmada medeni durum değişkenine göre sorulara verdikleri yanıtlarda gruplar arasında fark bulunmamaktadır.

Tablo 7

Ailedeki Rol Değişkenine Göre Katılımcıların Verdiği Yanıtların Ki-Kare Testi Sonuçları.

\begin{tabular}{|c|c|c|c|c|c|c|c|c|c|}
\hline & & & $\begin{array}{l} \\
\\
\end{array}$ & 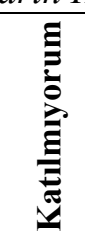 & 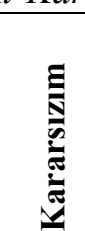 & 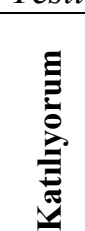 & 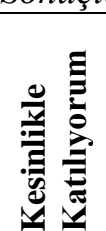 & $X^{2}$ & p \\
\hline \multirow{2}{*}{$\begin{array}{l}\text { Çocuğum uzaktan eğitim sürecinde } \\
\text { çevrimiçi derslere erişimde } \\
\text { sorun/sorunlar yaşadı. }\end{array}$} & \multirow[b]{2}{*}{ Toplam } & $\mathrm{n}$ & 78 & 78 & 176 & 101 & 125 & 6,796 & ,559 \\
\hline & & $\%$ & 14,0 & 14,0 & 31,5 & 18,1 & 22,4 & & \\
\hline \multirow{2}{*}{$\begin{array}{l}\text { Uzaktan eğitim ile öğrencilere eşit } \\
\text { öğrenme firsatları sunuldu. }\end{array}$} & \multirow{2}{*}{ Toplam } & $\mathrm{n}$ & 194 & 63 & 131 & 61 & 109 & 11,129 & ,195 \\
\hline & & $\%$ & 34,8 & 11,3 & 23,5 & 10,9 & 19,5 & & \\
\hline \multirow{2}{*}{$\begin{array}{l}\text { Uzaktan eğitim ile öğrencilere sunulan } \\
\text { öğrenme firsatları yeterlidir. }\end{array}$} & \multirow{2}{*}{ Toplam } & $\mathrm{n}$ & 194 & 107 & 146 & 64 & 47 & 5,473 & ,706 \\
\hline & & $\%$ & 34,8 & 19,2 & 26,2 & 11,5 & 8,4 & & \\
\hline \multirow{2}{*}{$\begin{array}{l}\text { Uzaktan eğitim ile çocuğum/çocuklarım } \\
\text { eğitim-öğretim olanaklarına diğer } \\
\text { çocuklarla eşit düzeyde erişti. }\end{array}$} & \multirow{2}{*}{ Toplam } & $\mathrm{n}$ & 131 & 71 & 142 & 100 & 114 & 11,537 & , 173 \\
\hline & & $\%$ & 23,5 & 12,7 & 25,4 & 17,9 & 20,4 & & \\
\hline
\end{tabular}

Yapılan araştırmada ailedeki rol değişkenine göre sorulara verdikleri yanıtlarda gruplar arasında fark bulunmamaktadır.

Tablo 8

Eğitim Düzeyi Değişkenine Göre Katılımcıların Verdiği Yanıtların Ki-Kare Testi Sonuçları.

\begin{tabular}{|c|c|c|c|c|c|c|c|c|c|c|}
\hline & & & & 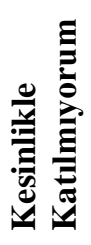 & 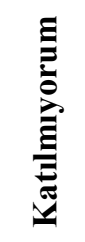 & 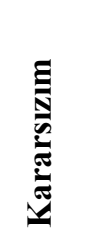 & 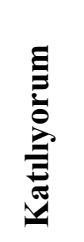 & 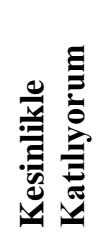 & $X^{2}$ & $\mathbf{P}$ \\
\hline \multirow{2}{*}{$\begin{array}{l}\text { Çocuğum uzaktan eğitim } \\
\text { sürecinde çevrimiçi }\end{array}$} & \multirow{2}{*}{$\begin{array}{l}\text { Eğitim } \\
\text { Durumu }\end{array}$} & \multirow{2}{*}{ İlkokul } & $\mathrm{n}$ & 18 & 9 & 8 & 9 & 18 & 51,298 & ,000 \\
\hline & & & $\%$ & 29,0 & 14,5 & 12,9 & 14,5 & 29,0 & & \\
\hline
\end{tabular}


derslere erişimde sorun/sorunlar yaşadi.

\begin{tabular}{|c|c|c|c|c|c|c|c|c|c|}
\hline & & & & & & & & & \\
\hline & Ortaokul & $\mathrm{n}$ & 13 & 5 & 10 & 13 & 17 & & \\
\hline & UrtaокuI & $\%$ & 22,4 & 8,6 & 17,2 & 22,4 & 29,3 & & \\
\hline & I ice & $\mathrm{n}$ & 27 & 29 & 70 & 26 & 46 & & \\
\hline & Lise & $\%$ & 13,6 & 14,6 & 35,4 & 13,1 & 23,2 & & \\
\hline & & $\mathrm{n}$ & 14 & 25 & 60 & 45 & 33 & & \\
\hline & Lisans & $\%$ & 7,9 & 14,1 & 33,9 & 25,4 & 18,6 & & \\
\hline & Lisansüs & $\mathrm{n}$ & 2 & 4 & 18 & 6 & 9 & & \\
\hline & & $\%$ & 5,12 & 10,25 & 46,15 & 15,38 & 23,09 & & \\
\hline & & $\mathrm{n}$ & 74 & 72 & 166 & 99 & 123 & & \\
\hline Toplam & & $\%$ & 13,9 & 13,5 & 31,1 & 18,5 & 23,0 & & \\
\hline & & $\mathrm{n}$ & 58 & 124 & 57 & 107 & 188 & 24,410 & ,225 \\
\hline 10piantil & & $\%$ & 10,9 & 23,2 & 10,7 & 20,0 & 35,2 & & \\
\hline & & $\mathrm{n}$ & 188 & 99 & 140 & 61 & 46 & 28,793 & ,092 \\
\hline Toplam & & $\%$ & 35,2 & 18,5 & 26,2 & 11,4 & 8,6 & & \\
\hline & & $\mathrm{n}$ & 127 & 67 & 139 & 93 & 108 & 25,060 & ,199 \\
\hline Toplam & & $\%$ & 23,8 & 12,5 & 26,0 & 17,4 & 20,2 & & \\
\hline
\end{tabular}

Katılımcıların "Çocuğum uzaktan eğitim sürecinde çevrimiçi derslere erişimde sorun/lar yaşadı" sorusuna verdikleri yanıtlara göre gruplar arasında anlamlı fark bulunmuştur. Bu sonuca göre sirasıyla ortaokul mezunu velilerin 30'u (\% 51,7), lisans mezunu katılımcıların 78'i (\% 44,0), ilkokul mezunu katılımcıların 27'si (\% 43,5), lisansüstü mezunu katılımcıların 15'i (\% 38,47), lise mezunu katılımcıların 72'si (\% 36,3) ve tüm katılımcıların 212'si (\% 41,5) uzaktan eğitim sürecinde çocuklarının derslere erişimde sorunlar yaşadığını belirtmiş̧ir.

Tablo 9

Çocuğunun Ĕ̆itim Durumu Değişkenine Göre Katılımcıların Verdiği Yanıtların Ki-Kare Testi Sonuçları

\begin{tabular}{|c|c|c|c|c|c|c|c|c|c|c|}
\hline & & & & 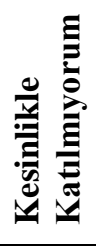 & 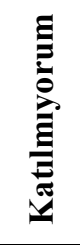 & 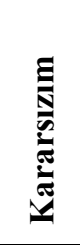 & 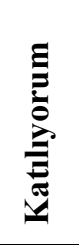 & 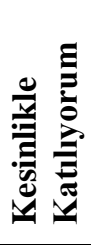 & $\mathbf{X}^{2}$ & $\mathbf{p}$ \\
\hline \multirow{2}{*}{$\begin{array}{l}\text { Çocuğum uzaktan eğitim } \\
\text { sürecinde çevrimiçi } \\
\text { derslere erişimde } \\
\text { sorun/sorunlar yaşadı. }\end{array}$} & \multirow{2}{*}{\multicolumn{2}{|c|}{ Toplam }} & $\mathrm{n}$ & 46 & 41 & 101 & 58 & 71 & 19,271 &, 082 \\
\hline & & & $\%$ & 14,5 & 12,9 & 31,9 & 18,3 & 22,4 & & \\
\hline \multirow{9}{*}{$\begin{array}{l}\text { Uzaktan eğitim ile } \\
\text { öğrencilere eşit öğrenme } \\
\text { firsatları sunuldu. }\end{array}$} & \multirow{8}{*}{$\begin{array}{l}\text { Çocuğun } \\
\text { Eğitim } \\
\text { Durumu }\end{array}$} & \multirow{2}{*}{ İlkokul } & $\mathrm{n}$ & 69 & 24 & 63 & 31 & 51 & 32,968 &, 001 \\
\hline & & & $\%$ & 29,0 & 10,1 & 26,5 & 13,0 & 21,4 & & \\
\hline & & \multirow{2}{*}{ Ortaokul } & $\mathrm{n}$ & 14 & 7 & 4 & 4 & 4 & & \\
\hline & & & $\%$ & 42,4 & 21,2 & 12,1 & 12,1 & 12,1 & & \\
\hline & & \multirow{2}{*}{ Lise } & $\mathrm{n}$ & 22 & 5 & 10 & 2 & 2 & & \\
\hline & & & $\%$ & 53,7 & 12,2 & 24,4 & 4,9 & 4,9 & & \\
\hline & & \multirow{2}{*}{ Lisans } & $\mathrm{n}$ & 1 & 0 & 0 & 0 & 4 & & \\
\hline & & & $\%$ & 20,0 & 0,0 & 0,0 & 0,0 & 80,0 & & \\
\hline & Toplam & & $\mathrm{n}$ & 106 & 36 & 77 & 37 & 61 & & \\
\hline
\end{tabular}


Uzaktan eğitim ile öğrencilere sunulan öğrenme firsatları yeterlidir.

Uzaktan eğitim ile çocuğum/çocuklarım eğitim-öğretim olanaklarına diğer çocuklarla eşit düzeyde erişti.

$\begin{array}{rrrrrrrr} & 33,4 & 11,4 & 24,3 & 11,7 & 19,2 & & \\ \mathrm{n} & 110 & 56 & 85 & 36 & 30 & 10,132 & , 604\end{array}$

Toplam

\begin{tabular}{llllll}
\hline$\%$ & 34,7 & 17,7 & 26,8 & 11,4 & 9,5
\end{tabular}

$\begin{array}{llllllll}\mathrm{n} & 78 & 44 & 72 & 54 & 69 & 18,951 & , 090\end{array}$

Toplam

\begin{tabular}{llllll}
\hline$\%$ & 24,6 & 13,9 & 22,7 & 17,0 & 21,8
\end{tabular}

Yapılan araştırmada katılımcıların çocuğunun eğitim düzeyi değişkenine göre "Uzaktan eğitim ile öğrencilere eşit öğrenme firsatları sunuldu." sorusuna verdikleri yanıtlara göre gruplar arasında anlamlı fark bulunmuştur. Bu sonuca göre sırasıyla çocuğu lise öğrenimi gören katılımcıların 27'si (\% 65,9), çocuğu ortaokul öğrenimi gören katılımcıların 21 'i $(\%$ 63,6), çocuğu ilkokul öğrenimi gören katılımcıların 93'ü (\% 39,1), çocuğu lisans öğrenimi gören katılımcıların 1'i (\% 20,0) ve tüm katılımcı velilerin 142'si (\% 44,8) uzaktan eğitim sürecinde çocuklarına eşit öğrenme firsatları sunulmadığını belirtmiştir.

Tablo 10

Gelir Düzeyi Değişkenine Göre Katılımcıların Verdiği Yanıtların Ki-Kare Testi Sonuçları

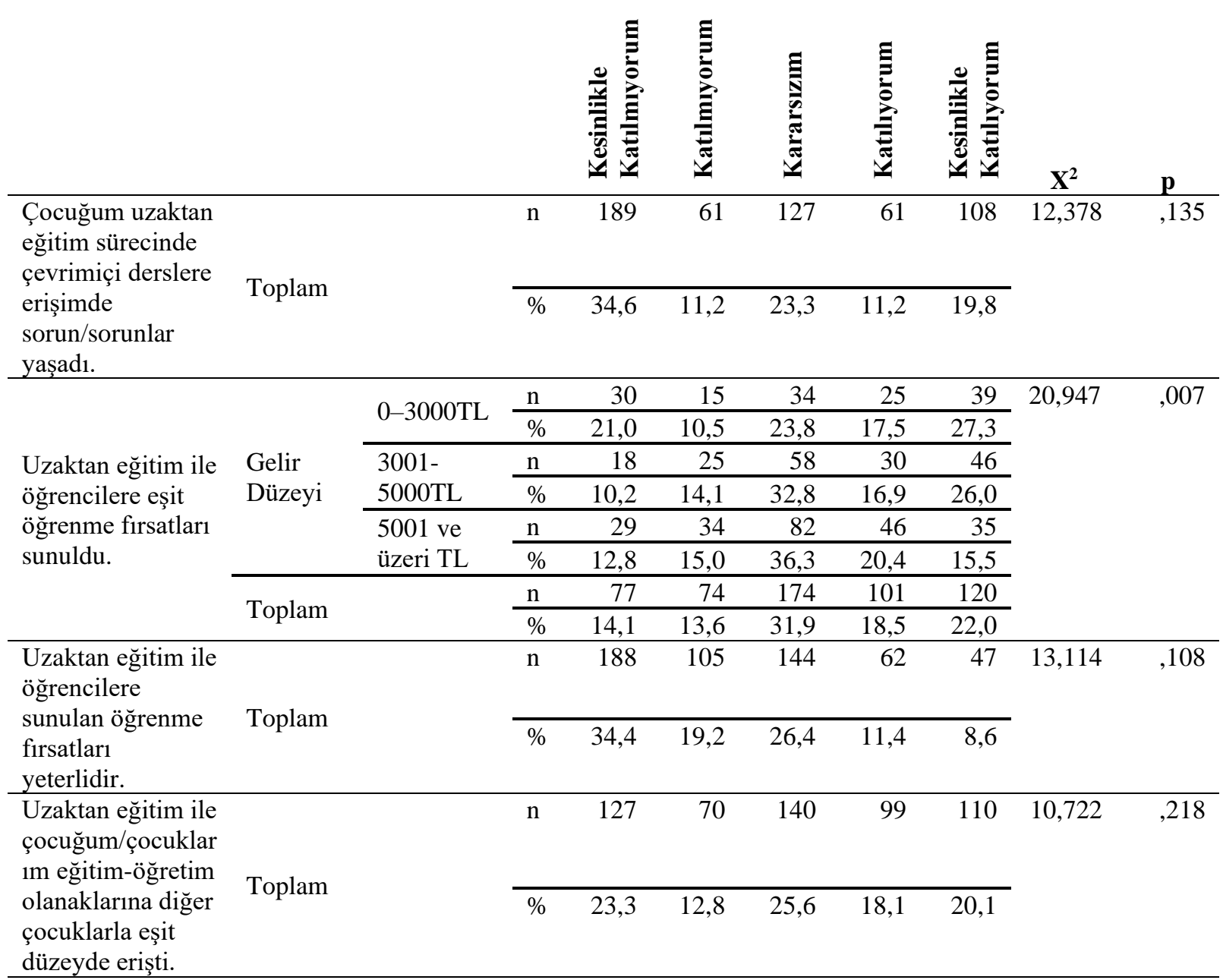


Katılımcıların "Uzaktan eğitim ile öğrencilere eşit öğrenme firsatları sunuldu." sorusuna verdikleri yanıtlara göre gruplar arasında anlamlı fark bulunmuştur. Bu sonuca göre sirasıyla gelir düzeyi 0-3000TL arasında olan katılımcıların 64'ü (\% 44,8), 3001-5000 TL arasinda olan katılımciların 76's1 (\% 42,9), 5001TL ve üzeri geliri olan katılımcıların 81'i (\% 35,9), tüm katılımc1 velilerin 221'i $(\%$ 40,5) uzaktan eğitim sürecinde çocuklarına eşit öğrenme firsatları sunulduğunu belirtmiştir.

Tablo 11

Katılımcıların Yaşadı̆̆ı Yer Değişkenine Göre Verdiği Yanıtların Ki-Kare Testi Sonuçları

\begin{tabular}{|c|c|c|c|c|c|c|c|c|c|c|}
\hline & & & & 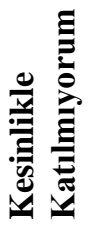 & 恶 & 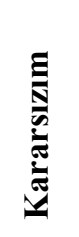 & 离 & 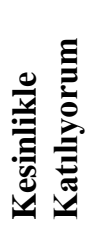 & $\mathbf{X}^{2}$ & $\mathbf{p}$ \\
\hline \multirow{2}{*}{$\begin{array}{l}\text { Çocuğum uzaktan } \\
\text { eğitim sürecinde } \\
\text { çevrimiçi derslere } \\
\text { erişimde } \\
\text { sorun/sorunlar } \\
\text { yaşadı. }\end{array}$} & \multirow[b]{2}{*}{ Toplam } & & $\mathrm{n}$ & 78 & 78 & 174 & 101 & 124 & 12,325 &, 137 \\
\hline & & & $\%$ & 14,1 & 14,1 & 31,4 & 18,2 & 22,3 & & \\
\hline \multirow{8}{*}{$\begin{array}{l}\text { Uzaktan eğitim ile } \\
\text { öğrencilere eşit } \\
\text { öğrenme firsatları } \\
\text { sunuldu. }\end{array}$} & \multirow{6}{*}{$\begin{array}{l}\text { Yaşadığ } 1 \\
\text { Yer }\end{array}$} & \multirow{2}{*}{ Köy } & $\mathrm{n}$ & 9 & 5 & 1 & 1 & 6 & 25,396 & ,001 \\
\hline & & & $\%$ & 40,9 & 22,7 & 4,5 & 4,5 & 27,3 & & \\
\hline & & \multirow{2}{*}{ İlçe } & $\mathrm{n}$ & 33 & 18 & 31 & 26 & 23 & & \\
\hline & & & $\%$ & 25,2 & 13,7 & 23,7 & 19,8 & 17,6 & & \\
\hline & & \multirow{2}{*}{ Şehir } & $\mathrm{n}$ & 151 & 40 & 97 & 34 & 80 & & \\
\hline & & & $\%$ & 37,6 & 10,0 & 24,1 & 8,5 & 19,9 & & \\
\hline & \multirow{2}{*}{\multicolumn{2}{|c|}{ Toplam }} & $\mathrm{n}$ & 193 & 63 & 129 & 61 & 109 & & \\
\hline & & & $\%$ & 34,8 & 11,4 & 23,2 & 11,0 & 19,6 & & \\
\hline \multirow{2}{*}{$\begin{array}{l}\text { Uzaktan eğitim ile } \\
\text { öğrencilere } \\
\text { sunulan öğrenme } \\
\text { firsatları } \\
\text { yeterlidir. }\end{array}$} & \multirow[b]{2}{*}{ Toplam } & & $\mathrm{n}$ & 191 & 107 & 146 & 64 & 47 & 9,257 & ,321 \\
\hline & & & $\%$ & 34,4 & 19,3 & 26,3 & 11,5 & 8,5 & & \\
\hline \multirow{8}{*}{$\begin{array}{l}\text { Uzaktan eğitim ile } \\
\text { çocuğum/çocuklar } \\
\text { 1m eğitim-öğretim } \\
\text { olanaklarına diğer } \\
\text { çocuklarla eşit } \\
\text { düzeyde erişti. }\end{array}$} & \multirow{6}{*}{$\begin{array}{l}\text { Yaşadığ } 1 \\
\text { Yer }\end{array}$} & \multirow{2}{*}{ Köy } & $\mathrm{n}$ & 7 & 5 & 7 & 0 & 3 & 17,993 & ,021 \\
\hline & & & $\%$ & 31,8 & 22,7 & 31,8 & 0,0 & 13,6 & & \\
\hline & & \multirow{2}{*}{ İlçe } & $\mathrm{n}$ & 18 & 14 & 40 & 30 & 29 & & \\
\hline & & & $\%$ & 13,7 & 10,7 & 30,5 & 22,9 & 22,1 & & \\
\hline & & \multirow{2}{*}{ Şehir } & $\mathrm{n}$ & 105 & 50 & 95 & 70 & 82 & & \\
\hline & & & $\%$ & 26,1 & 12,4 & 23,6 & 17,4 & 20,4 & & \\
\hline & \multirow{2}{*}{\multicolumn{2}{|c|}{ Toplam }} & $\mathrm{n}$ & 130 & 69 & 142 & 100 & 114 & & \\
\hline & & & $\%$ & 23,4 & 12,4 & 25,6 & 18,0 & 20,5 & & \\
\hline
\end{tabular}

Katılımcıların "Uzaktan eğitim ile öğrencilere eșit öğrenme firsatları sunuldu." ve "Uzaktan eğitim ile çocuğum/çocuklarım eğitim-öğretim olanaklarına diğer çocuklarla eşit düzeyde erişti." sorularına verdikleri yanıtlara göre gruplar arasında anlamlı fark bulunmuştur. Bu sonuca göre sırasıyla yerleșim yeri köy olan 14 (\% 63,6), katılımcının, yerleșim yeri șehir olan 191 (\% 47,6) katılımcının, yerleşim yeri ilçe olan 51 (\% 38,9) katılımcının ve tüm katılımcıların 256'sı (\% 46,2) uzaktan eğitim ile öğrencilere eşit öğrenme firsatları sunulmadığını; yerleşim yeri köy olan 12 (\% 54,5) katılımcı, yerleşim yeri şehir olan $155(\% 38,5)$ katılımcı, yerleşim yeri ilçe olan $32(\% 24,4)$ katılımcı ve tüm katılımcıların 199'u (\% 35,8) uzaktan eğitim ile çocuğum/çocuklarım eğitim-öğretim olanaklarına diğer çocuklarla eşit düzeyde erişmediğini; bununla birlikte yerleşim yeri ilçe olan 59 (\% 45,0) katılımcılar ile tüm katılımcıların 214'ü $(\%$ 38,50) uzaktan eğitim ile çocuğum/çocuklarım eğitim-öğretim olanaklarına diğer çocuklarla eşit düzeyde eriştiğini belirtmiştir. 
Tablo 12

İnternet Erişim Şekli Değişkenine Göre Katılımcıların Verdiği Yanıtların Ki-Kare Testi Sonuçları

\begin{tabular}{|c|c|c|c|c|c|c|c|c|c|c|}
\hline & & & & 总 & E & 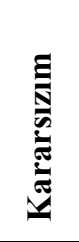 & 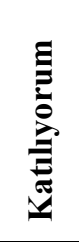 & 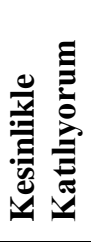 & $\mathbf{X}^{2}$ & $\mathbf{p}$ \\
\hline \multirow{6}{*}{$\begin{array}{l}\text { Çocuğum uzaktan } \\
\text { eğitim sürecinde } \\
\text { çevrimiçi derslere } \\
\text { erişimde } \\
\text { sorun/sorunlar } \\
\text { yaşadı. }\end{array}$} & \multirow{4}{*}{$\begin{array}{l}\text { İnternet } \\
\text { Erişim } \\
\text { Şekli }\end{array}$} & \multirow{2}{*}{ Kotalı } & $\mathrm{n}$ & 15 & 15 & 42 & 25 & 41 & 6,979 & ,137 \\
\hline & & & $\%$ & 10,9 & 10,9 & 30,4 & 18,1 & 29,7 & & \\
\hline & & \multirow{2}{*}{ Sinırsız } & $\mathrm{n}$ & 63 & 63 & 134 & 76 & 84 & & \\
\hline & & & $\%$ & 15,0 & 15,0 & 31,9 & 18,1 & 20,0 & & \\
\hline & \multirow{2}{*}{ Toplam } & & $\mathrm{n}$ & 78 & 78 & 176 & 101 & 125 & & \\
\hline & & & $\%$ & 14,0 & 14,0 & 31,5 & 18,1 & 22,4 & & \\
\hline \multirow{6}{*}{$\begin{array}{l}\text { Uzaktan eğitim ile } \\
\text { öğrencilere eşit } \\
\text { öğrenme firsatları } \\
\text { sunuldu. }\end{array}$} & \multirow{4}{*}{$\begin{array}{l}\text { İnternet } \\
\text { Erişim } \\
\text { Şekli }\end{array}$} & \multirow{2}{*}{ Kotalı } & $\mathrm{n}$ & 46 & 18 & 30 & 14 & 30 & 1,404 & ,844 \\
\hline & & & $\%$ & 33,3 & 13,0 & 21,7 & 10,1 & 21,7 & & \\
\hline & & \multirow{2}{*}{ Sinırsız } & $\mathrm{n}$ & 148 & 45 & 101 & 47 & 79 & & \\
\hline & & & $\%$ & 35,2 & 10,7 & 24,0 & 11,2 & 18,8 & & \\
\hline & \multirow{2}{*}{ Toplam } & & $\mathrm{n}$ & 194 & 63 & 131 & 61 & 109 & & \\
\hline & & & $\%$ & 34,8 & 11,3 & 23,5 & 10,9 & 19,5 & & \\
\hline \multirow{6}{*}{$\begin{array}{l}\text { Uzaktan eğitim ile } \\
\text { öğrencilere } \\
\text { sunulan öğrenme } \\
\text { firsatları } \\
\text { yeterlidir. }\end{array}$} & \multirow{4}{*}{$\begin{array}{l}\text { İnternet } \\
\text { Erişim } \\
\text { Şekli }\end{array}$} & \multirow{2}{*}{ Kotalı } & $\mathrm{n}$ & 57 & 21 & 34 & 14 & 12 & 4,212 & ,378 \\
\hline & & & $\%$ & 41,3 & 15,2 & 24,6 & 10,1 & 8,7 & & \\
\hline & & \multirow{2}{*}{ Sinırsız } & $\mathrm{n}$ & 137 & 86 & 112 & 50 & 35 & & \\
\hline & & & $\%$ & 32,6 & 20,5 & 26,7 & 11,9 & 8,3 & & \\
\hline & \multirow{2}{*}{ Toplam } & & $\mathrm{n}$ & 194 & 107 & 146 & 64 & 47 & & \\
\hline & & & $\%$ & 34,8 & 19,2 & 26,2 & 11,5 & 8,4 & & \\
\hline \multirow{6}{*}{$\begin{array}{l}\text { Uzaktan eğitim ile } \\
\text { çocuğum/çocuklar } \\
\text { 1m eğitim-öğretim } \\
\text { olanaklarına diğer } \\
\text { çocuklarla eşit } \\
\text { düzeyde erişti. }\end{array}$} & \multirow{4}{*}{$\begin{array}{l}\text { İnternet } \\
\text { Erişim } \\
\text { Şekli }\end{array}$} & \multirow{2}{*}{ Kotalı } & $\mathrm{n}$ & 42 & 18 & 35 & 28 & 15 & 12,573 & ,014 \\
\hline & & & $\%$ & 30,4 & 13,0 & 25,4 & 20,3 & 10,9 & & \\
\hline & & \multirow{2}{*}{ Sinırsiz } & $\mathrm{n}$ & 89 & 53 & 107 & 72 & 99 & & \\
\hline & & & $\%$ & 21,2 & 12,6 & 25,5 & 17,1 & 23,6 & & \\
\hline & \multirow{2}{*}{ Toplam } & & $\mathrm{n}$ & 131 & 71 & 142 & 100 & 114 & & \\
\hline & & & $\%$ & 23,5 & 12,7 & 25,4 & 17,9 & 20,4 & & \\
\hline
\end{tabular}

Katılımcıların "Uzaktan eğitim ile çocuğum/çocuklarım eğitim-öğretim olanaklarına diğer çocuklarla eşit düzeyde erişti." Sorusuna verdikleri yanıtlara göre gruplar arasında anlamlı fark bulunmuştur. Bu sonuca göre sırasıyla internet erişim şekli sınırsız olan katılımcıların 171'i (\% 40,7) ve tüm katılımcıların 224'ü (\% 38,3) uzaktan eğitim ile çocuğum/çocuklarım eğitim-öğretim olanaklarına diğer çocuklarla eşit düzeyde eriştiğini, internet erişim şekli kotalı olan $60(\% 43,4)$ katılımcı ile tüm katılımcıların 202'si (\% 36,2) uzaktan eğitim ile çocuğum/çocuklarım eğitim-öğretim olanaklarına diğer çocuklarla eşit düzeyde erişmediğini belirtmiştir.

Tablo 13

Katılımcıların Milli Ĕgitim Bakanlı̆̆ı (MEB) ve Yükseköğretim Kurulunun (YÖK) ücretsiz olarak kullanıma sunduğu internet hizmetinden haberdar misınız? sorusuna katılımcıların verdiğ yanıtların KiKare testi sonuçlart.

\begin{tabular}{|c|c|c|c|c|c|c|c|c|c|c|}
\hline & & & & 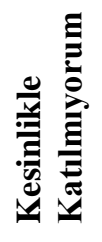 & 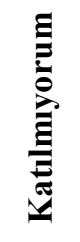 & 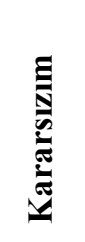 & 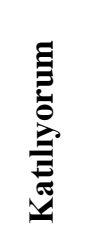 & 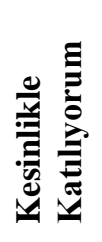 & $\mathbf{X}^{2}$ & $\mathbf{p}$ \\
\hline \multirow{2}{*}{$\begin{array}{l}\text { Çocuğum uzaktan } \\
\text { eğitim sürecinde }\end{array}$} & MEB & \multirow{2}{*}{ Evet } & $\mathrm{n}$ & 33 & 31 & 93 & 49 & 43 & 11,636 &, 020 \\
\hline & YÖK & & & 13,3 & 12,4 & 37,3 & 19,7 & 17,3 & & \\
\hline
\end{tabular}




\begin{tabular}{|c|c|c|c|c|c|c|c|c|c|c|}
\hline \multirow{5}{*}{$\begin{array}{l}\text { çevrimiçi derslere } \\
\text { erişimde } \\
\text { sorun/sorunlar } \\
\text { yaşadı. }\end{array}$} & \multirow{3}{*}{ Hayır } & \multirow{3}{*}{ Hayır } & & & & & & & & \\
\hline & & & \multirow[t]{2}{*}{$\mathrm{n}$} & 45 & 47 & 83 & 52 & 82 & & \\
\hline & & & & 14,6 & 15,2 & 26,9 & 16,8 & 26,5 & & \\
\hline & \multirow{2}{*}{ Toplam } & & $\mathrm{n}$ & 78 & 78 & 176 & 101 & 125 & & \\
\hline & & & & 14,0 & 14,0 & 31,5 & 18,1 & 22,4 & & \\
\hline \multirow{6}{*}{$\begin{array}{l}\text { Uzaktan eğitim ile } \\
\text { öğrencilere eşit } \\
\text { öğrenme firsatları } \\
\text { sunuldu. }\end{array}$} & \multirow{4}{*}{$\begin{array}{l}\text { MË } \\
\text { YÖK }\end{array}$} & \multirow[b]{2}{*}{ Evet } & $\mathrm{n}$ & 91 & 23 & 57 & 28 & 50 & \multirow[t]{6}{*}{2,263} & \multirow[t]{6}{*}{,687 } \\
\hline & & & & 36,5 & 9,2 & 22,9 & 11,2 & 20,1 & & \\
\hline & & \multirow{2}{*}{ Hayır } & $\mathrm{n}$ & 103 & 40 & 74 & 33 & 59 & & \\
\hline & & & & 33,3 & 12,9 & 23,9 & 10,7 & 19,1 & & \\
\hline & \multirow{2}{*}{ Toplam } & & $\mathrm{n}$ & 194 & 63 & 131 & 61 & 109 & & \\
\hline & & & & 34,8 & 11,3 & 23,5 & 10,9 & 19,5 & & \\
\hline \multirow{6}{*}{$\begin{array}{l}\text { Uzaktan eğitim ile } \\
\text { ögrencilere } \\
\text { sunulan öğrenme } \\
\text { firsatlar. } \\
\text { yeterlidir. }\end{array}$} & \multirow{4}{*}{$\begin{array}{l}\text { MEB } \\
\text { YÖK }\end{array}$} & \multirow{2}{*}{ Evet } & $\mathrm{n}$ & 89 & 41 & 69 & 31 & 19 & \multirow[t]{6}{*}{2,968} & \multirow[t]{6}{*}{, 563} \\
\hline & & & & 35,7 & 16,5 & 27,7 & 12,4 & 7,6 & & \\
\hline & & & $\mathrm{n}$ & 105 & 66 & 77 & 33 & 28 & & \\
\hline & & Hayır & & 34,0 & 21,4 & 24,9 & 10,7 & 9,1 & & \\
\hline & \multirow{2}{*}{ Toplam } & & $\mathrm{n}$ & 194 & 107 & 146 & 64 & 47 & & \\
\hline & & & & 34,8 & 19,2 & 26,2 & 11,5 & 8,4 & & \\
\hline \multirow{6}{*}{$\begin{array}{l}\text { Uzaktan eğitim ile } \\
\text { çocuğum/çocuklar } \\
\text { 1m eğitim-öğretim } \\
\text { olanaklarına diğer } \\
\text { çocuklarla eşit } \\
\text { düzeyde erişti. }\end{array}$} & \multirow{4}{*}{$\begin{array}{l}\text { MEB } \\
\text { YÖK }\end{array}$} & \multirow{2}{*}{ Evet } & $\mathrm{n}$ & 41 & 37 & 73 & 42 & 56 & \multirow[t]{6}{*}{14,883} & \multirow[t]{6}{*}{,005 } \\
\hline & & & & 16,5 & 14,9 & 29,3 & 16,9 & 22,5 & & \\
\hline & & Науй & $\mathrm{n}$ & 90 & 34 & 69 & 58 & 58 & & \\
\hline & & Hayır & & 29,1 & 11,0 & 22,3 & 18,8 & 18,8 & & \\
\hline & \multirow{2}{*}{\multicolumn{2}{|c|}{ Toplam }} & $\mathrm{n}$ & 131 & 71 & 142 & 100 & 114 & & \\
\hline & & & & 23,5 & 12,7 & 25,4 & 17,9 & 20,4 & & \\
\hline
\end{tabular}

Katılımcıların "Çocuğum uzaktan eğitim sürecinde çevrimiçi derslere erişimde sorun/sorunlar yaşadı" ve "Uzaktan eğitim ile çocuğum/çocuklarım eğitim-öğretim olanaklarına diğer çocuklarla eşit düzeyde erişti" sorularına verdikleri yanıtlara göre gruplar arasında anlamlı fark bulunmuştur. Bu sonuca göre Milli Eğitim Bakanlığı (MEB) ve Yükseköğretim Kurulunun (YÖK) ücretsiz olarak kullanıma sunduğu internet hizmetinden haberdar misınız sorusuna verdikleri yanıtlar değerlendirildiğinde haberdar olmayan katılımcıların 134'ü (\% 44,3); haberdar olan katılımcıların 92'si (\% 37,0) ve tüm katılımcıların 226's1 (\% 40,5) çocuğunun uzaktan eğitim sürecinde çevrimiçi derslere erişimde sorun/sorunlar yaşadığını belirtmişlerdir. Milli Eğitim Bakanlığı (MEB) ve Yükseköğretim Kurulunun (YÖK) ücretsiz olarak kullanıma sunduğu internet hizmetinden haberdar olan katılımcıların 98'i $(\% 39,4)$ uzaktan eğitim ile çocuğunun/çocuklarının eğitim-öğretim olanaklarına diğer çocuklarla eşit düzeyde eriştiğini belirtmiştir.

Tablo 14

Milli Ĕ̈itim Bakanlı̆̆ı (MEB) ve Yükseköğretim Kurulunun (YÖK) Ücretsiz Olarak Kullanıma Sunduğu Internet Yeterli Oldu Mu? Sorusuna Katılımcıların Verdikleri Yanıtların Ki-Kare Testi Sonuçları

\begin{tabular}{|c|c|c|c|c|c|c|c|c|c|c|}
\hline & & & & 常 & 㤩 & 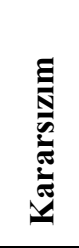 & E & 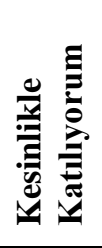 & $\mathbf{X}^{2}$ & $\mathbf{p}$ \\
\hline \multirow{6}{*}{$\begin{array}{l}\text { Çocuğum uzaktan } \\
\text { eğitim sürecinde } \\
\text { çevrimiçi derslere } \\
\text { erişimde } \\
\text { sorun/sorunlar } \\
\text { yaşadi. }\end{array}$} & \multirow{4}{*}{$\begin{array}{l}\text { MEB } \\
\text { YÖK } \\
\text { İnternet } \\
\text { yeterli mi }\end{array}$} & \multirow{2}{*}{ Evet } & $\mathrm{n}$ & 14 & 10 & 27 & 9 & 13 & 7,336 &, 119 \\
\hline & & & $\%$ & 19,2 & 13,7 & 37,0 & 12,3 & 17,8 & & \\
\hline & & \multirow{2}{*}{ Hayır } & $\mathrm{n}$ & 36 & 33 & 84 & 58 & 79 & & \\
\hline & & & $\%$ & 12,4 & 11,4 & 29,0 & 20,0 & 27,2 & & \\
\hline & \multirow{2}{*}{ Toplam } & & $\mathrm{n}$ & 50 & 43 & 111 & 67 & 92 & & \\
\hline & & & $\%$ & 13,8 & 11,8 & 30,6 & 18,5 & 25,3 & & \\
\hline \multirow{3}{*}{$\begin{array}{l}\text { Uzaktan eğitim ile } \\
\text { öğrencilere eşit } \\
\text { öğrenme firsatları }\end{array}$} & \multirow{3}{*}{$\begin{array}{l}\text { MEB } \\
\text { YÖK } \\
\text { İnternet }\end{array}$} & \multirow{2}{*}{ Evet } & $\mathrm{n}$ & 13 & 3 & 17 & 11 & 29 & 31,762 & ,000 \\
\hline & & & $\%$ & 17,8 & 4,1 & 23,3 & 15,1 & 39,7 & & \\
\hline & & Hayır & $\mathrm{n}$ & 118 & 36 & 67 & 24 & 45 & & \\
\hline
\end{tabular}




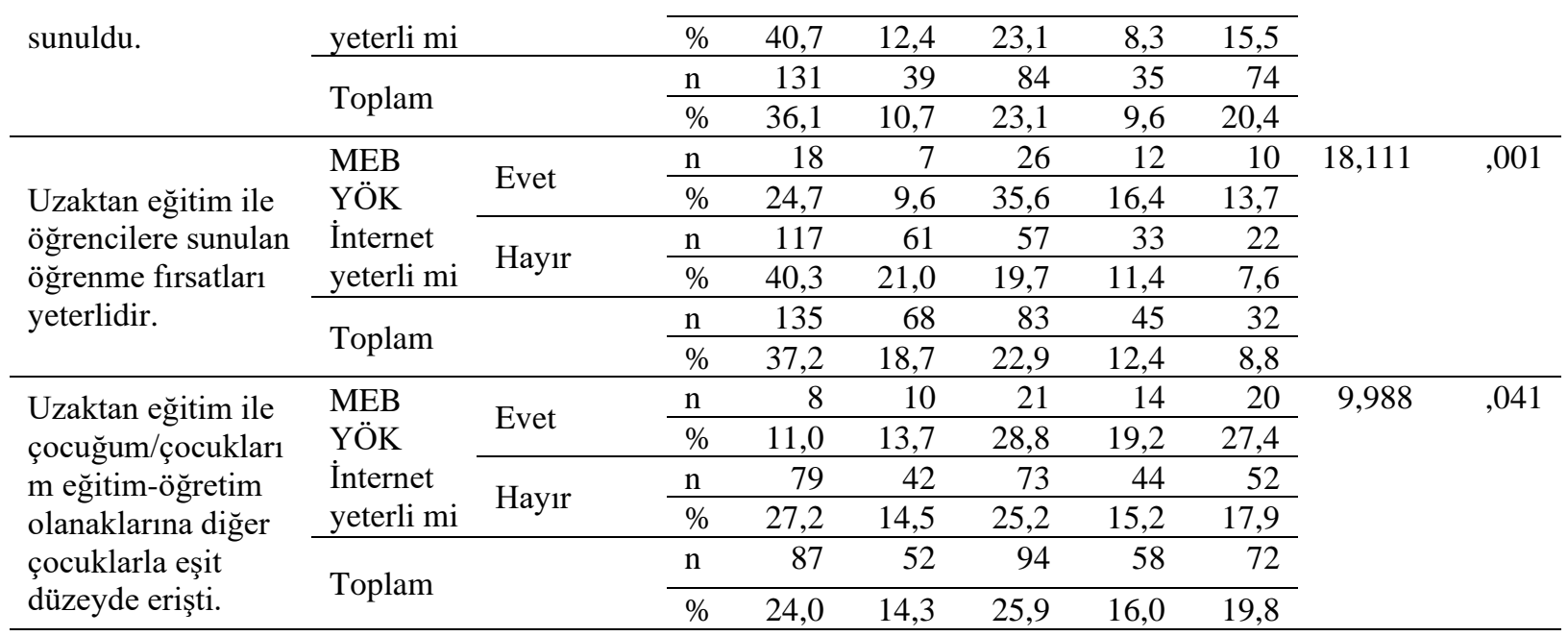

Katılımcıların "Uzaktan eğitim ile çocuğum/çocuklarım eğitim-öğretim olanaklarına diğer çocuklarla eşit düzeyde erişti", "Uzaktan eğitim ile öğrencilere sunulan öğrenme firsatları yeterlidir" ve "Uzaktan eğitim ile çocuğum/çocuklarım eğitim-öğretim olanaklarına diğer çocuklarla eşit düzeyde erişti" sorularına verdikleri yanıtlara göre gruplar arasında anlamlı fark bulunmuştur. $\mathrm{Bu}$ sonuca göre Milli Eğitim Bakanlığı (MEB) ve Yükseköğretim Kurulunun (YÖK) ücretsiz olarak kullanıma sunduğu internet yeterli oldu mu sorusuna verdikleri yanıtlar değerlendirildiğinde yeterli bulan katılımcıların 40’1 (\% 54,8) uzaktan eğitim ile öğrencilere eşit öğrenme firsatları sunulduğunu, yetersiz bulan katılımcıların 154'ü (\% 53,1) uzaktan eğitim ile öğrencilere eşit öğrenme fırsatlarının sunulmadığını belirtmiştir. Milli Eğitim Bakanlığı (MEB) ve Yükseköğretim Kurulunun (YÖK) ücretsiz olarak kullanıma sunduğu internet yeterli bulan katılımc1ların 35'i (\% 35,3), yetersiz bulan katılımcıların 178'i $(\%$ 61,3) ve tüm katılımc1ların 203'ü $(\%$ 55,9) uzaktan eğitim ile öğrencilere sunulan öğrenme firsatlarının yetersiz olduğunu belirtmişlerdir. Milli Eğitim Bakanlığı (MEB) ve Yükseköğretim Kurulunun (YÖK) ücretsiz olarak kullanıma sunduğu internet yeterli bulan katılımcıların 34'ü $(\% 46,6)$ uzaktan eğitim ile çocuğunun/çocuklarının eğitim öğretim olanaklarına diğer çocuklarla eşit düzeyde eriştiğini, yetersiz bulan katılımcıların 121 'i $(\% 41,7)$ çocuğunun/çocuklarının eğitim öğretim olanaklarına diğer çocuklarla eşit düzeyde erişemediğini belirtmiştir.

Tablo 15

Uzaktan Eğitim Sürecinde Teknoloji Harcamalarında Artış Yaşandı Mı? Sorusuna Verdikleri Yanıtların Ki-Kare Testi Sonuçları

\begin{tabular}{|c|c|c|c|c|c|c|c|c|c|}
\hline & & & 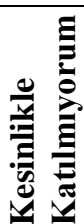 & 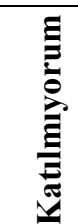 & 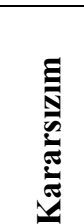 & 莸 & 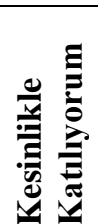 & $X^{2}$ & p \\
\hline \multirow{2}{*}{$\begin{array}{l}\text { Çocuğum uzaktan eğitim sürecinde } \\
\text { çevrimiçi derslere erişimde } \\
\text { sorun/sorunlar yaşadı. }\end{array}$} & \multirow{2}{*}{ Toplam } & $\mathrm{n}$ & 78 & 78 & 176 & 101 & 125 & 8,902 & ,064 \\
\hline & & $\%$ & 14,0 & 14,0 & 31,5 & 18,1 & 22,4 & & \\
\hline \multirow{2}{*}{$\begin{array}{l}\text { Uzaktan eğitim ile öğrencilere eşit } \\
\text { öğrenme firsatları sunuldu. }\end{array}$} & \multirow{2}{*}{ Toplam } & $\mathrm{n}$ & 194 & 63 & 131 & 61 & 109 & 8,264 & ,082, \\
\hline & & $\%$ & 34,8 & 11,3 & 23,5 & 10,9 & 19,5 & & \\
\hline \multirow{2}{*}{$\begin{array}{l}\text { Uzaktan eğitim ile öğrencilere sunulan } \\
\text { öğrenme firsatları yeterlidir. }\end{array}$} & \multirow{2}{*}{ Toplam } & $\mathrm{n}$ & 194 & 107 & 146 & 64 & 47 & 6,113 & ,191 \\
\hline & & $\%$ & 34,8 & 19,2 & 26,2 & 11,5 & 8,4 & & \\
\hline \multirow{2}{*}{$\begin{array}{l}\text { Uzaktan eğitim ile çocuğum/çocuklarım } \\
\text { eğitim-öğretim olanaklarına diğer } \\
\text { çocuklarla eşit düzeyde erişti. }\end{array}$} & \multirow{2}{*}{ Toplam } & $\mathrm{n}$ & 131 & 71 & 142 & 100 & 114 & 6,041 & ,196 \\
\hline & & $\%$ & 23,5 & 12,7 & 25,4 & 17,9 & 20,4 & & \\
\hline
\end{tabular}


Katılımcıların Uzaktan eğitim sürecinde teknoloji harcamalarında artış yaşandı mı? sorusuna verdikleri yanıtlara göre gruplar arasında fark bulunmamaktadır.

Tablo 16

Uzaktan Eğitim Sürecinde Teknoloji Harcamalarında Artış Yaşandı Mı Sorusuna Hayır Yanıtı Veren Katılımcıların Yanıtlarının Ki-Kare Testi Sonuçları

\begin{tabular}{|c|c|c|c|c|c|c|c|c|c|c|c|}
\hline & & & & & 㫣 & E & 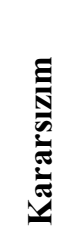 & 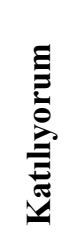 & 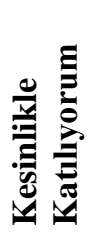 & $\mathbf{X}^{2}$ & $\mathbf{p}$ \\
\hline \multirow{6}{*}{$\begin{array}{l}\text { Çocuğum uzaktan } \\
\text { eğitim sürecinde } \\
\text { çevrimiçi derslere } \\
\text { erişimde } \\
\text { sorun/sorunlar } \\
\text { yaşadı. }\end{array}$} & \multirow{4}{*}{\multicolumn{2}{|c|}{$\begin{array}{l}\text { Harcamalarda } \\
\text { Artış }\end{array}$}} & Yeterli & $\mathrm{n}$ & 34 & 30 & 58 & 23 & 25 & 19,295 &, 001 \\
\hline & & & Ekipman & $\%$ & 20,0 & 17,6 & 34,1 & 13,5 & 14,7 & & \\
\hline & & & Ekonomik & $\mathrm{n}$ & 26 & 18 & 50 & 32 & 59 & & \\
\hline & & & Yetersizlik & $\%$ & 14,1 & 9,7 & 27,0 & 17,3 & 31,9 & & \\
\hline & \multirow{2}{*}{\multicolumn{3}{|c|}{ Toplam }} & $\mathrm{n}$ & 60 & 48 & 108 & 55 & 84 & & \\
\hline & & & & $\%$ & 16,9 & 13,5 & 30,4 & 15,5 & 23,7 & & \\
\hline \multirow{6}{*}{$\begin{array}{l}\text { Uzaktan eğitim ile } \\
\text { öğrencilere eşit } \\
\text { öğrenme fırsatları } \\
\text { sunuldu. }\end{array}$} & \multirow{4}{*}{$\begin{array}{l}\text { Harcama } \\
\text { larda } \\
\text { Artış }\end{array}$} & & & $\mathrm{n}$ & 43 & 17 & 44 & 24 & 42 & 5,516 & ,238 \\
\hline & & & pman & $\%$ & 25,3 & 10,0 & 25,9 & 14,1 & 24,7 & & \\
\hline & & & onomik & $\mathrm{n}$ & 63 & 25 & 38 & 22 & 37 & & \\
\hline & & & ersizlik & $\%$ & 34,1 & 13,5 & 20,5 & 11,9 & 20,0 & & \\
\hline & \multirow{2}{*}{\multicolumn{3}{|c|}{ Toplam }} & $\mathrm{n}$ & 106 & 42 & 82 & 46 & 79 & & \\
\hline & & & & $\%$ & 29,9 & 11,8 & 23,1 & 13,0 & 22,3 & & \\
\hline \multirow{6}{*}{$\begin{array}{l}\text { Uzaktan eğitim ile } \\
\text { öğrencilere } \\
\text { sunulan öğrenme } \\
\text { firsatları } \\
\text { yeterlidir. }\end{array}$} & \multirow{4}{*}{$\begin{array}{l}\text { Harcama } \\
\text { larda } \\
\text { Artış }\end{array}$} & \multirow{2}{*}{\multicolumn{2}{|c|}{$\begin{array}{l}\text { Yeterli } \\
\text { Ekipman }\end{array}$}} & $\mathrm{n}$ & 44 & 27 & 53 & 23 & 23 & 12,211 & ,016 \\
\hline & & & & $\%$ & 25,9 & 15,9 & 31,2 & 13,5 & 13,5 & & \\
\hline & & \multirow{2}{*}{\multicolumn{2}{|c|}{$\begin{array}{l}\text { Ekonomik } \\
\text { Yetersizlik }\end{array}$}} & $\mathrm{n}$ & 77 & 28 & 41 & 25 & 14 & & \\
\hline & & & & $\%$ & 41,6 & 15,1 & 22,2 & 13,5 & 7,6 & & \\
\hline & \multirow{2}{*}{\multicolumn{3}{|c|}{ Toplam }} & $\mathrm{n}$ & 121 & 55 & 94 & 48 & 37 & & \\
\hline & & & & $\%$ & 34,1 & 15,5 & 26,5 & 13,5 & 10,4 & & \\
\hline \multirow{6}{*}{$\begin{array}{l}\text { Uzaktan eğitim ile } \\
\text { çocuğum/çocuklar } \\
\text { 1m eğitim-öğretim } \\
\text { olanaklarına diğer } \\
\text { çocuklarla eşit } \\
\text { düzeyde erişti. }\end{array}$} & \multirow{4}{*}{$\begin{array}{l}\text { Harcama } \\
\text { larda } \\
\text { Artış }\end{array}$} & \multirow{2}{*}{\multicolumn{2}{|c|}{$\begin{array}{l}\text { Yeterli } \\
\text { Ekipman }\end{array}$}} & $\mathrm{n}$ & 30 & 17 & 38 & 34 & 51 & 17,929 & ,001 \\
\hline & & & & $\%$ & 17,6 & 10,0 & 22,4 & 20,0 & 30,0 & & \\
\hline & & \multirow{2}{*}{\multicolumn{2}{|c|}{$\begin{array}{l}\text { Ekonomik } \\
\text { Yetersizlik }\end{array}$}} & $\mathrm{n}$ & 54 & 29 & 46 & 29 & 27 & & \\
\hline & & & & $\%$ & 29,2 & 15,7 & 24,9 & 15,7 & 14,6 & & \\
\hline & \multirow{2}{*}{\multicolumn{3}{|c|}{ Toplam }} & $\mathrm{n}$ & 84 & 46 & 84 & 63 & 78 & & \\
\hline & & & & $\%$ & 23,7 & 13,0 & 23,7 & 17,7 & 22,0 & & \\
\hline
\end{tabular}

Katılımcıların "Çocuğum uzaktan eğitim sürecinde çevrimiçi derslere erişimde sorun/sorunlar yaşadı", "Uzaktan eğitim ile öğrencilere sunulan öğrenme firsatları yeterlidir" ve "Uzaktan eğitim ile çocuğum/çocuklarım eğitim-öğretim olanaklarına diğer çocuklarla eşit düzeyde erişti” sorularına verdikleri yanıtlara göre gruplar arasında anlamlı fark bulunmuştur. Bu sonuca göre uzaktan eğitim sürecinde teknoloji harcamalarında artış yaşandı $\mathrm{m} ı$ sorusuna hayır yanıtı verenlerin gerekçelerine yönelik soruya yeterli ekipmanının olduğunu belirtenlerin 64'ü (\% 37,6) çocuğunun uzaktan eğitim sürecinde çevrimiçi derslere erişimde sorun/sorunlar yaşamadığını, ekonomik yetersizlik nedeniyle harcamalarında artış olmadığını belirtenlerin 91'i (\% 49,2) çocuğunun uzaktan eğitim sürecinde çevrimiçi derslere erişimde sorun/sorunlar yaşadığını belirtmiştir. 
Tablo 17

Çocuk Sayısı Değişkenine Göre Katılımcıların Verdiği Yanıtların Ki-Kare Testi Sonuçları

\begin{tabular}{|c|c|c|c|c|c|c|c|c|c|}
\hline & & & 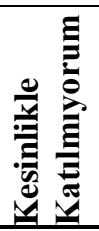 & 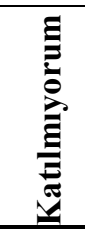 & 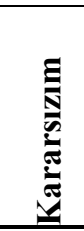 & 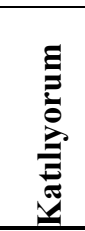 & 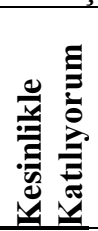 & $\mathbf{X}^{2}$ & $\mathbf{p}$ \\
\hline \multirow{2}{*}{$\begin{array}{l}\text { Çocuğum uzaktan eğitim sürecinde } \\
\text { çevrimiçi derslere erişimde } \\
\text { sorun/sorunlar yaşadı. }\end{array}$} & \multirow[b]{2}{*}{ Toplam } & $\mathrm{n}$ & 192 & 62 & 131 & 61 & 109 & 11,491 & ,487 \\
\hline & & $\%$ & 34,6 & 11,2 & 23,6 & 11,0 & 19,6 & & \\
\hline \multirow{2}{*}{$\begin{array}{l}\text { Uzaktan eğitim ile öğrencilere eşit } \\
\text { öğrenme fırsatları sunuldu. }\end{array}$} & \multirow{2}{*}{ Toplam } & $\mathrm{n}$ & 76 & 78 & 175 & 101 & 125 & 12,883 & ,378 \\
\hline & & $\%$ & 13,7 & 14,1 & 31,5 & 18,2 & 22,5 & & \\
\hline \multirow{2}{*}{$\begin{array}{l}\text { Uzaktan eğitim ile öğrencilere sunulan } \\
\text { öğrenme fırsatları yeterlidir. }\end{array}$} & \multirow{2}{*}{ Toplam } & $\mathrm{n}$ & 194 & 106 & 144 & 64 & 47 & 11,288 & ,504 \\
\hline & & $\%$ & 35,0 & 19,1 & 25,9 & 11,5 & 8,5 & & \\
\hline \multirow{2}{*}{$\begin{array}{l}\text { Uzaktan eğitim ile çocuğum/çocuklarım } \\
\text { eğitim-öğretim olanaklarına diğer } \\
\text { çocuklarla eşit düzeyde erişti. }\end{array}$} & \multirow{2}{*}{ Toplam } & $\mathrm{n}$ & 131 & 70 & 142 & 98 & 114 & 14,605 & ,264 \\
\hline & & $\%$ & 23,6 & 12,6 & 25,6 & 17,7 & 20,5 & & \\
\hline
\end{tabular}

Yapılan araştırmada çocuk sayısı değişkenine göre verdikleri yanıtlarda gruplar arasında fark bulunmamaktadir.

Tablo 18

Yaş Değişkenine Göre Katılımcıların Verdiği Yanıtların Ki-Kare Testi Sonuçları

\begin{tabular}{|c|c|c|c|c|c|c|c|c|c|c|}
\hline & & & & 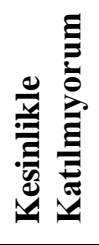 & 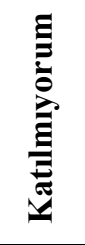 & 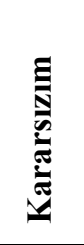 & 恶 & 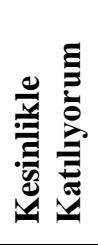 & $\mathbf{X}^{2}$ & $\mathbf{p}$ \\
\hline \multirow{8}{*}{$\begin{array}{l}\text { Çocuğum uzaktan } \\
\text { eğitim sürecinde } \\
\text { çevrimiçi derslere } \\
\text { erişimde } \\
\text { sorun/sorunlar } \\
\text { yaşadı. }\end{array}$} & \multirow{6}{*}{ Yaşınız } & \multirow{2}{*}{ 20-30 Yaş } & $\mathrm{n}$ & 14 & 4 & 10 & 3 & 11 & \multirow[t]{8}{*}{20,771} & \multirow[t]{8}{*}{, 008} \\
\hline & & & $\%$ & 33,3 & 9,5 & 23,8 & 7,1 & 26,2 & & \\
\hline & & $31-40$ Yas & $\mathrm{n}$ & 95 & 37 & 70 & 48 & 67 & & \\
\hline & & $31-40$ Yaş & $\%$ & 30,0 & 11,7 & 22,1 & 15,1 & 21,1 & & \\
\hline & & $41 \mathrm{ve}$ & $\mathrm{n}$ & 80 & 21 & 40 & 9 & 29 & & \\
\hline & & üzeri Yaş & $\%$ & 44,7 & 11,7 & 22,3 & 5,0 & 16,2 & & \\
\hline & \multirow{2}{*}{ Toplam } & & $\mathrm{n}$ & 189 & 62 & 120 & 60 & 107 & & \\
\hline & & & $\%$ & 35,1 & 11,5 & 22,3 & 11,2 & 19,9 & & \\
\hline \multirow{2}{*}{$\begin{array}{l}\text { Uzaktan eğitim ile } \\
\text { ögrrencilere eşit } \\
\text { ögrenme firsatları } \\
\text { sunuldu. }\end{array}$} & \multirow[b]{2}{*}{ Toplam } & & $\mathrm{n}$ & 74 & 78 & 169 & 100 & 117 & \multirow[t]{2}{*}{7,641} & \multirow[t]{2}{*}{469} \\
\hline & & & $\%$ & 13,8 & 14,5 & 31,4 & 18,6 & 21,7 & & \\
\hline \multirow{2}{*}{$\begin{array}{l}\text { Uzaktan eğitim ile } \\
\text { ögrencilere } \\
\text { sunulan öğrenme } \\
\text { firsatları } \\
\text { yeterlidir. }\end{array}$} & \multirow[b]{2}{*}{ Toplam } & & $\mathrm{n}$ & 189 & 104 & 141 & 57 & 47 & \multirow[t]{2}{*}{3,436} & \multirow[t]{2}{*}{,904 } \\
\hline & & & $\%$ & 35,1 & 19,3 & 26,2 & 10,6 & 8,7 & & \\
\hline \multirow{2}{*}{$\begin{array}{l}\text { Uzaktan eğitim ile } \\
\text { çocuğum/çocuklar } \\
\text { 1m eğitim-öğretim } \\
\text { olanaklarına diğer } \\
\text { çocuklarla eşit } \\
\text { düzeyde erişti. }\end{array}$} & \multirow[b]{2}{*}{ Toplam } & & $\mathrm{n}$ & 126 & 71 & 136 & 97 & 108 & \multirow[t]{2}{*}{7,609} & \multirow[t]{2}{*}{473} \\
\hline & & & $\%$ & 23,4 & 13,2 & 25,3 & 18,0 & 20,1 & & \\
\hline
\end{tabular}


Katılımcıların "Çocuğum uzaktan eğitim sürecinde çevrimiçi derslere erişimde sorun/sorunlar yaşadı” gruplar arasında anlamlı fark bulunmuştur. Bu sonuca göre sırasıyla 41 ve üzeri yaş aralığındaki katılımcıların 101'i (\% 55,4), 20-30 yaş aralığında olanların 18'i (\% 42,8) ve 31-40 yaş aralığında olanların 132'si $(\% 41,7)$ ve tüm katılımcıların 251'i $(\% 46,6)$ çocuğunun uzaktan eğitim sürecinde çevrimiçi derslere erişimde sorun/sorunlar yaşadığını belirtmiştir.

\section{Sonuç, Tartışma ve Öneriler}

Yapılan araştırmada cinsiyet, medeni durum ve ailedeki rol değişkenlerine göre katılımcı velilerin verdikleri yanıtlarda gruplar arasında fark bulunmamıştır. Bozkurt'a göre (2020) Koronavirüs salgını ile çocukların okullarından evlerine dönmeleri ile özellikle annelerin eğitsel rolleri ve sorumlulukları artmıştır. Çocuğun uzaktan eğitim sürecinde çevrimiçi derslere erişimde sorun/lar yaşayıp yaşamadığ açısından velilerin eğitim düzeyi değişkenine göre gruplar arasında anlamlı fark bulunmuştur. Ebeveyn eğitim düzeyinin ögrencilerin uzaktan e ğitim sürecinde derslere erişimine etkisinin olmadığ belirlenmiştir. Koronavirüs salgın döneminde öğrenci ve öğretmenlerin eğitime erişimde ihtiyaç duyulan dijital yeterlilik ve becerilere sahip olmadıkları ve ebeveynlerin bilişim teknolojilerini kullanabilmede çocuklarına yardım edebilmeleri beklendiği, öğrencilerin katılımda yaşadığı eşitsizliklerin bir diğer kaynağının velilerin eğitim düzeylerinin olduğu görülmektedir (Alipio, 2020; Ali, 2020; Bozkurt vd., 2020; Doyle, 2020). Bu araştırmada ebeveyn eğitim düzeyinin öğrencilerin uzaktan eğitime erişimine etkisinin olmadığı sonucu alanyazın ile farklılık göstermektedir. Salgın döneminde uzaktan eğitimin tarafları olarak öğretmen, öğrenci, anne-babalar ile diğer eğitim paydaşlarının eğitime erişime yönelik yeterlik ve becerilerinin yetersiz olması, eşitsizlik açısından farklılıkların azalması yönünde etkili olduğuna yordanabilir.

Uzaktan eğitim ile ögrencilere eşit ögrenme firsatları sunulması açısından öğrencilerin eğitim düzeyine göre gruplar arasında anlamlı fark bulunmuştur. Lise ve ortaokullarda farklı sınıf düzeylerinde $(5,8,9$ ve 12) uzaktan eğitim sürecinin bir bölümünde yüz yüze eğitime geçilmesi ve bu düzeydeki öğrencilerin merkezi sınava girecek olmaları yaşanan firsat eşitsizliğinin bu grup velilerince daha fazla hissedilmesine neden olmuştur. Genel olarak elde edilen bulgulara göre çocuğun eğitim gördüğü tüm düzeylerde firsat eşitsizliğinin yaşandığı görülmektedir. Chang ve Satako'ya (2020) göre, hemen hemen tüm ülkeler, öğretmenler ve okul yöneticileri, öğrenciler ve velilerle iletişimi desteklemek için mevcut uygulamaların yanı sıra, canlı dersler ve çevrimiçi kurslar düzenlemektedirler. $\mathrm{Bu}$ araştırma sonucunda bütün kademelerde yaşanan eşitsizliğin önlenmesine yönelik çalışmalar yapıldığ 1 görülmektedir. $\mathrm{Bu}$ araştırma sonucuna göre velilerin çocuk sayısı uzaktan eğitim sürecinde çevrimiçi derslere erişimde sorun yaşama, öğrencilere eşit öğrenme firsatları sunulması ve sunulan ögrenme firsatlar yeterli olması ile çocukların eğitim-öğretim olanaklarına diğer çocuklarla eşit düzeyde erişmesi açısından gruplar arasında fark bulunmamıştır. Alanyazında çocukların salgın sürecinde eğitime erişimde ailelerin teknolojik olanaklarının önemli olması yanında aile içerisinde kardeşler arasında sorunlar yaşandığı görülmektedir (Imran, Zeshan ve Pervaiz, 2020). Araştırmaya katılan ebeveynlerin yaş değişkenine göre uzaktan eğitim sürecinde çevrimiçi derslere erişimde çocuklarının sorun yaşayıp yaşamadi $\breve{g}_{l}(P=, 008)$ açısından gruplar arasında fark bulunmuştur.

Uzaktan ĕgitim ile ögrencilere eşit öğrenme firsatları sunulması sorusuna verilen yanıtlar incelendiğinde gelir düzeyi değişkenine göre gruplar arasında anlamlı fark bulunmuştur. Bu sonuç Milli Eğitim Bakanlığı'nın Eğitim Bilişim Ağ tarafindan yeterli görüldüğünü göstermektedir. Eğitim süreçlerinde de sosyoekonomik düzeyin eğitim çıktıları üzerinde önemli bir etkisi vardır (Özer, 2020; Suna, Tanberkan ve Özer, 2020; Suna vd., 2020). Uzaktan eğitim sürecinde gelir düzeyiyle ilişkili olarak evde daha fazla imkâna sahip olan öğrencilerin diğer öğrencilerden daha avantajlı olabileceği açıkça görülmektedir (Eren Suna ve Özer, 2020). Velilerin yaşadığı yer değişkenine göre uzaktan eğitim ile ögrencilere eşit ögrenme firsatları sunulması ve çocuklarının ĕgitim-ögretim olanaklarına diğer çocuklarla eşit düzeyde erişmesine verilen yanıtlarda 
gruplar arasında anlamlı fark bulunmuştur. Yerleşim yeri köy olan çocuklar uzaktan eğitim sürecinde özellikle teknolojik alt yapı yetersizliği sebebiyle ilçe ve şehirde yaşayan çocuklara göre eşit öğrenme firsatlarının sunumu ve erişimi konusunda dezavantajlı durumdadır.

İnternet erişim şekline göre uzaktan ĕgitim ile çocuğum/çocuklarım ĕgitim-öğretim olanaklarına diğer çocuklarla eşit düzeyde erişmesi açısından velilerin yanıtlarında gruplar arasında anlamlı fark bulunmuştur. Türkiye İstatistik Kurumu (TÜİK) Hanehalkı Bilişim Teknolojileri Kullanım Araştırması sonuçlarına göre Türkiye genelinde her on haneden birinde internet bağlantısı bulunmamaktadır (Türk Eğitim Derneği Sosyal-Kültürel Yap1 (TEDMEM), 2020). MEB/YÖK tarafindan ücretsiz olarak kullanıma sunulan internet hizmetinden haberdar olup olmama durumuna göre "Çocuğum uzaktan eğitim sürecinde çevrimiçi derslere erişimde sorun/sorunlar yaşadı. $(\mathrm{P}=, 020)$ " ve "Uzaktan eğitim ile çocuğum/çocuklarım eğitim-öğretim olanaklarına diğer çocuklarla eşit düzeyde erişti."; velilerin MEB/YÖK tarafından ücretsiz olarak kullanıma sunduğu internet hizmetinin yeterli olup olmamasına göre "Uzaktan eğitim ile öğrencilere eşit ögrrenme firsatları sunuldu.", "Uzaktan eğitim ile ögrencilere sunulan ögrenme firsatlarl yeterlidir. "Uzaktan eğitim ile çocuğum/çocuklarım eğitim-öğretim olanaklarına diğer çocuklarla eşit düzeyde erişti." verdikleri yanıtlarda gruplar arasında anlamlı fark bulunmuştur. TEDMEM (2020) internete erişim ve teknolojik imkânlardaki yetersizlikler uzaktan öğrenmenin etkililiğini azaltmıştır. Uzaktan eğitim sürecinde teknoloji harcamalarında artış yaşanıp yaşanmadığ konusunda velilerin verdikleri yanıtlara göre gruplar arasında fark bulunmamıştır. Salgın döneminde eğitimde açıklık, erişilebilirlik, esneklik temeline dayanan çevrimiçi uzaktan eğitim uygulamaları özyönelimli ve özyönetimli (Knowles, 1975) becerileri gerektirdiğinden öğrencilerin eğitimciler ve ebeveynler tarafından desteklenmesi gerektiği gibi uzaktan eğitime teknolojik ekipmanlar ile erişim olanaklarına da sahip olmaları gerektiği görülmüştür (Bozkurt, 2020). Uzaktan eğitim sürecinde teknoloji harcamalarında artış yaşamama gerekçesi açısından "Çocuğum uzaktan eğitim sürecinde çevrimiçi derslere erişimde sorun/sorunlar yaşadl.", "Uzaktan ĕgitim ile öğrencilere sunulan ögrenme firsatları yeterlidir." ve "Uzaktan ĕgitim ile çocuğum/çocuklarım eğitim-öğretim olanaklarına diğer çocuklarla eşit düzeyde erişti." sorularına velilerin verdikleri yanıtlarda gruplar arasında anlamlı fark bulunmuştur. TEDMEM (2020) uzaktan öğrenme sürecinin öğrenciler açısından en önemli verimlilik göstergesi, öğrencilerin evlerinde sahip olduğu teknolojik imkânlardır. Araştırmada uzaktan eğitimde eşit öğrenme firsatları sunulması, eğitim firsatlarına eşit erişim ve çevrim içi derslere erişimde sorun yaşamaya yönelik katılımcı ebeveynlerin farklı düşünmektedirler. Türkiye'yi ve tüm dünyayı eğitim bağlamında derinden etkileyen Koronavirüs salgın sürecindeki uzaktan eğitimde öğrencilere sunulan eğitim firsatlarına erişimlerinde bölgesel farklılıklara göre yaşadıkları sorunların çözümü için altyapı eksiklikleri giderilmelidir. Salgın sonrasında da öğrencilerin çevrimiçi platformlara erişimlerine yönelik internet ve teknolojik ekipman sağlanmalı, kullanımına yönelik eğitim verilmelidir. Uzaktan eğitim ile sunulan fırsatlara erişim sağlayamayan öğrencilerin yaşadığı öğrenme kayıplarının giderilmesine yönelik eğitim kurumları arasında iş birliği yapılmalıdır. Koronavirüs salgın sonrasında uzaktan eğitime erişim açısından dezavantajlı duruma düşen öğrenciler için telafi eğitimleri yapılmalıdır. Okulların açılması ile özellikle alt sosyoekonomik düzeylerde olan ve çeşitli imkânsızlıklar nedeniyle verimli bir uzaktan eğitim süreci geçiremeyen öğrencilerin akademik açıdan destekleyici uygulamalar yapılmalıdır. Uzaktan eğitim sürecinde yaşanan eşitsizliğin azaltılmasında MEB/YÖK tarafindan sunulan ücretsiz internet hizmetinin kullanımının yaygınlaştırılması ve bilinirliğinin artırılması amacıyla alternatif tanıtım araçlarının kullanılması ve kotasının artırılması sağlanmalıdır.

\section{Yazarların Katkı Oranı}

Bu makaleye birinci yazarın \%50, ikinci yazarın $\% 50$ oranında katkısı vardır.

\section{Çıkar Çatışması}

Bu çalışmada çıkar çatışması oluşturacak bir husus yoktur. 


\section{Kaynaklar}

Acemoğlu, D. and Pischke, J.-S. (2001). Changes in the wage structure, family income, and children's education. European Economic Review, 45, 890-904.

Ali, W. (2020). Online and remote learning in higher education institutes: A necessity in light of COVID19. Pandemic. Higher Education, 10(3), 16-25. https://doi.org/10.5539/hes.v10n3p16

Alipio, M. (2020). Education during COVID-19 era: Are learners in a less-economically developed country ready for e-learning?. Retrieved from https://ideas.repec.org/p/zbw/esrepo/216098.html in 17.10.2020.

Anderson, E. (2007). Fair opportunity in education: A democratic equality perspective. Ethics, 117, 595622

Ashford, N. (2015). Özgür toplumun ilkeleri. (Çev. Can Madenci), 4. Baskı, Liberte Yayınları.

Bozkurt, A. (2020). Educational technology research patterns in the realm of the digital knowledge age. Journal of Interactive Media in Education, 2020(1), 18. DOI: http://doi.org/10.5334/jime.570

Bozkurt, A., Jung, I., Xiao, J., Vladimirschi, V., Schuwer, R., Egorov, G. and Paskevicius, M. (2020). A global outlook to the interruption of education due to COVID-19 Pandemic: Navigating in a time of uncertainty and crisis. Asian Journal of Distance Education, 15(1), 1-126. DOI: https://doi.org/10.5281/zenodo.3878572

Buyruk, H. (2008). Eğitimde yaşanan toplumsal eşitsizlikler ve farklılaşan eğitim rotaları: üniversite ögrrencilerinin deneyimlerine dayalı bir araştırma. Eğitim Bilim Toplum, 7(25), 6-45.

Chang, G. C. and Satako, Y. (2020). How are countries addressing the Covid-19 challenges in education? A snapshot of policy measures. Retrieved from https://gemreportunesco.wordpress.com/2020/03/24/how-are-countries-addressing-thecovid-19challenges-in-education-a-snapshot-of-policy-measures in 13.10.2020.

Doyle, O. (2020). COVID-19: Exacerbating educational inequalities?. Public policy. Retrieved from http://publicpolicy.ie/papers/covid-19-exacerbating-educational-inequalities in 12.10.2020.

Edwards, N. (1946). Problems of equality of opportunity in education. Review of Educational Research, 16(1), 46-49.

Gamoran, A. and Long, D. A. (2007). Equality of educational opportunity: a 40 year retrospective. In M. Teese,Richard; Lamb, Stephen; Duru-Bellat (Eds.), International Studies in Educational Inequality, Theory and Policy (pp. 23-47). Dordrecht: Springer.

Işık, M. ve Bahat, İ. (2021). COVID 19: Eğitimde yeni arayışlar. Üniversite Araştırmaları Dergisi, 4(1), 82-89.

Knowles, M. S. (1975). Self-directed learning: A guide for learners and teachers. New York: Association Press.

Küçüker, E. (2010). Türkiye'de Eğitim Planlamas1 Neyi Hedefliyor. International Conference on New Trends in Education and Their Implications, 11-13 Kasim, Antalya, 153-157. 
Mercik, V. (2015). Ĕ̈itimde firsat eşitliği, toplumsal genel başarı ve adalet ilişkisi: PISA projesi kapsamında Finlandiya ve Türkiye deneyimlerinin karşılaştırllması, Yüksek Lisans Tezi, Sosyal Bilimler Enstitüsü, Balıkesir Üniversitesi.

Organisation for Economic Co-operation and Development. (2012). Equity and quality in education: Supporting disadvantaged students and schools, OECD Publishing. Retrieved from http://dx.doi.org/10.1787/9789264130852-en in 17.10.2020.

Ömür, Y. E., Bahat, İ. and Ernas, S. (2017). An analysis of fundamental high schools in the context of equality in education. International Online Journal of Educational Sciences, 9(2), 401-419.

Özer, M. ve Eren Suna, H. (2020). COVID-19 Salgını ve Eğitim, Şeker, M., Özer, A. ve Korkut, C. (Editörler), Küresel Salgının Anatomisi Insan ve Toplumun Geleceği içinde (ss. 171-192). Türkiye Bilimler Akademisi, Ankara.

Özer, M. (2020). What PISA tells us about performance of education systems? Bartın University Journal of Faculty of Education, 9(2), 217-228.

Patton, M. Q. (2014). Nitel araştırma ve değerlendirme yöntemleri (M. Bütün ve S. B. Demir, çev.). Ankara: Pegem Akademi.

Sarıbaş, S. ve Babadağ, G. (2015). Temel eğitimin temel sorunları. Anadolu Eğitim Liderliği ve Öğretim Dergisi, 3(1), 18-34.

Satz, D. (2008). Equality, adequacy, and educational policy. Education Finance and Policy, 3(4), 424443.

Schleicher, A. (2009). Securing quality and equity in education: lessons from PISA. Prospects, 39(3), 251-263.

Suna, H. E., Tanberkan, H., Gür, B. S., Perc, M. and Özer, M. (2020). Socioeconomic status and school type as predictors of academic achievement. Journal of Economy, Culture and Society, 61(1), 124.

Suna, H. E., Tanberkan, H. and Özer, M. (2020). Changes in literacy of students in Turkey by years and school types: Performance of students in PISA applications. Journal of Measurement and Evaluation in Education and Psychology, 11(1), 76-97.

Tezcan, M. (1985). Ĕgitim sosyolojisi (Dördüncü baskı) Ankara: Ankara Üniversitesi Eğitim Bilimleri Fakültesi Yayınları.

Türk Eğitim Derneği. (2007). Türkiye'de okul öncesi eğitim ve ilköğretim sistemi temel sorunlar ve çözüm önerileri, özet rapor (Birinci Baskı). Ankara: Adım Ajans.

Yıldırım, A. ve Şimşek, H. (2013). Sosyal bilimlerde nitel araştırma yöntemleri (9. Bask1). Ankara: Seçkin Yayıncılık.

Y1ldı, A. ve Akar Vural, R. (2020). Covid-19 pandemisi ve derinleşen eğitim eşitsizlikleri. Türk Tabipleri Birliği Covid-19 pandemisi altıncı ay değerlendirme raporu. Ankara: Türk Tabipler Birliği. 


\section{Extended Abstract}

\section{Introduction}

The purpose of this research is to determine the problems and solutions experienced by students in accessing education in the context of technology during the Coronavirus (Covid-19) outbreak. Coronavirus outbreak affected teachers and parents, especially students. In this period, when online education was carried out through different applications, students have different learning experiences in their access to education. In the context of equal opportunity, the differences in opportunities for students to have educational technologies and problems in the education system have become more pronounced. In this process, it is seen as a major and important problem that the students of all levels have inequalities of opportunity in having digital technologies, substructure requirements, and even digital competencies. The problems of this research have been identified as determining problems in accessing online courses during the online education process and the equal learning opportunities that students should have, determining whether online education opportunities are sufficient, determining technological equipment needs and solutions, the effects of the epidemic period on students and suggestions for improving this period.

Identifying the inequalities of opportunity and solution suggestions shows the importance of this research. Besides, the arrangements for students' access to education and the measures to be taken to ensure equal opportunity and meet the requirements, will reduce the negative effects of the process experienced both individually and socially.

\section{Method}

In this research, because the findings were revealed in line with the opinion of the parents of children who study at different schools, a scanning design was used from the patterns of the quantitative research method. In the December of 2020-2021 academic year, data were collected with the electronic survey form prepared for the research. The survey prepared to collect the data consists of 23 questions. While the first eight-question about demographic features (gender, marital status, role in the family, education level, school level of children, the total income of the family, residence), and the next nine about the determination of technological opportunities and access to education in online education, the next questions were prepared using the 5 points Likert scale. It was analyzed with the SPSS 25 statistical program.

\section{Findings}

Some of the participants stated that they bought new technological devices (smartphone, tablet, desktop computer, laptop, other) to access online lessons during the online education process, half of them did not buy any new devices; some of them stated that they were aware of the free internet service offered by the Ministry of Public Education (MEB)/Council of Higher Education (YÖK), and half of them did not. Some participants stated that their internet access was limited, while the majority stated that it was unlimited.

No difference was found between the groups in terms of problems in accessing online classes during the online education process, providing equal learning opportunities to students, sufficient learning opportunities offered to the students, and equal access to educational opportunities according to the variables (gender, marital status, role in the family, the number of children in the family, the type of internet access, whether there was an increase in technology expenditures). A significant difference was found between the groups according to the variables of age, residence, education, and income level of the parents; whether the free internet service of MEB/YÖK was sufficient or not, and their awareness of this service. 


\section{Conclusion, Discussion and Recommendations}

In the study, no difference was found between the groups in the responses of participant parents to the questions according to the variables of gender, marital status, role in the family, education level, and the number of children. According to the education level of parents, there were problems with children's access to online classes, but the education level of parents was not found to be directly effective in access to lessons, equal opportunities, and equal access in the online education process. According to the findings obtained in general, it is seen that there is an inequality of opportunity at all levels where the child is educated.

It has been concluded that according to the variables of residence, parents whose settlement is villages, cities, and districts, respectively, do not provide equal learning opportunities to students through online education and their children do not have equal access to education and training opportunities with other children; besides, it has been concluded that their children have equal access to educational opportunities with other children through online education.

Children whose settlement is a village are disadvantaged in terms of the provision and access of equal learning opportunities compared to children living in the district and city during the online education process. The lack of technological infrastructure in the place where they live creates a disadvantage especially in accessing the services provided. It has been determined that according to the internet access method, half of those with limited internet access do not have equal educational opportunities with other children in online education, half of those with unlimited internet access have equal access. 